\title{
Tectono-metamorphic evolution of the pre-Athabasca basement within the Wollaston-Mudjatik Transition Zone, Saskatchewan
}

\begin{tabular}{|r|l|}
\hline Journal: & Canadian Journal of Earth Sciences \\
\hline Manuscript ID & cjes-2015-0136.R2 \\
\hline Manuscript Type: & Article \\
\hline Date Submitted by the Author: & 12 -Jan-2016 \\
\hline Complete List of Authors: & $\begin{array}{l}\text { Jeanneret, Pauline; Laboratoire Chrono-environnement, Université de } \\
\text { Bourgogne-Franche-Comté } \\
\text { Goncalves, Philippe; Laboratoire Chrono-environnement, Université de } \\
\text { Bourgogne-Franche-Comté } \\
\text { Durand, Cyril ; EA 4515 Laboratoire Génie Civil et géo-Environnement, } \\
\text { Université de Lille 1 } \\
\text { Trap, Pierre; Laboratoire Chrono-environnement, Université de Bourgogne- } \\
\text { Franche-Comté } \\
\text { Marquer, Didier; laboratoire Chrono-environnement, Université de } \\
\text { Bourgogne-Franche-Comté } \\
\text { Quirt, David; AREVA Resources Canada Inc. } \\
\text { Ledru, Patrick; AREVA Resources Canada Inc. }\end{array}$ \\
\hline \multirow{2}{*}{ Keyword: } & $\begin{array}{l}\text { Tectono-metamorphic evolution, Athabasca Basin, Trans-Hudson Orogen, } \\
\text { Wollaston-Mudjatik Transition Zone, Uranium }\end{array}$ \\
\hline
\end{tabular}

\section{SCHOLARONE \\ Manuscripts}


1 Tectono-metamorphic evolution of the pre-Athabasca basement within the Wollaston-Mudjatik

2 Transition Zone, Saskatchewan

3 Pauline Jeanneret ${ }^{1} *$, Philippe Goncalves ${ }^{1}$, Cyril Durand ${ }^{2}$, Pierre Trap $^{1}$, Didier Marquer ${ }^{1}$, David Quirt ${ }^{3}$, 4 and Patrick Ledru ${ }^{3}$

5

$6{ }^{1}$ Laboratoire Chrono-environnement, Université de Bourgogne-Franche-Comté, 16 route de Gray, 725000 Besançon, France.

82 EA 4515 Laboratoire Génie Civil et géo-Environnement, Université de Lille 1, 59655 Villeneuve 9 d'Ascq, France.

${ }^{3}$ AREVA Resources Canada Inc. $817-45^{\text {th }}$ St West, Saskatoon, S7K 3X5, CANADA.

$11 *$ Corresponding author: Pauline Jeanneret (pauline.jeanneret@univ-fcomte.fr) 


\section{Abstract}

The Paleoproterozoic tectono-metamorphic evolution of the pre-Athabasca basement $(\sim 1.7 \mathrm{Ga})$ within the Wollaston-Mudjatik Transition Zone (WMTZ) (Saskatchewan, Canada) has been characterized using both exposed basement and drill cores from the Wolly-McClean exploration drilling project. The finite ductile strain pattern of the WMTZ results from the superposition of two tectono-metamorphic events M1-D1 and M2-D2. M1-D1 is associated with the development of a gently-dipping foliation striking $\mathrm{N} 90^{\circ}-100^{\circ}$ and a southward decrease in peak pressures from up to $10 \mathrm{kbar}$ in the Cochrane River area down to 6 kbar in the Wolly-McClean exploration drilling project. The M2-D2 event is responsible for the main northeasterly trend of the WMTZ that developed in a sinistral transpressional tectonic regime during the final oblique collision of the Trans-Hudson Orogeny. Thermobarometric estimations on M2-D2 assemblages show that the studied area was re-equilibrated at about 4 to $5 \mathrm{kbar}$ and $750-825^{\circ} \mathrm{C}$. The basement has thus been affected by a differential isothermal decompression event between D1 and D2 that allowed the juxtaposition of the deepest northern-eastern domains and the Wolly-McClean exploration drilling project, at the same structural level. These results suggest that the basement exposed to the north-east of the Athabasca Basin is not an analog of the basement located beneath the eastern Athabasca Basin where uranium-enriched granitic pegmatites and granites are known. We also suggest that uranium-enriched melt produced during the early M1-D1 stage of partial melting in the deep crust were transferred to the mid-crust, owing to D2 shear zones, were they have differentiated to produce uranium-bearing pegmatites.

Key words: Tectono-metamorphic evolution; Athabasca Basin; Trans-Hudson Orogen; WollastonMudjatik Transition Zone; Uranium

\section{Résumé}

L'évolution tectono-métamorphique Paléoprotérozoique du socle pré-Athabasca $(\sim 1.7 \mathrm{Ga})$ de la Zone de Transition Mudjatik-Wollaston (ZTMW) (Saskatchewan) a été définie à partir du socle affleurant et des forages du projet Wolly-McClean. Le champ de déformation finie ductile résulte de la superposition de deux évènements tectono-métamorphique M1-D1 et M2-D2. M1-D1 est associé au 
54 développement d'une foliation peu inclinée orientée $\mathrm{N} 90^{\circ}-100^{\circ}$ et à un pic de pression décroissant

55 vers le sud avec plus de 10 kbar à la rivière Cochrane, jusqu'à 6 kbar dans la zone de forage du projet

56 Wolly-McClean. L'évènement M2-D2 est responsable de la structuration majeure Nord-Est de la

57 ZTMW qui s'est développée dans un régime transpressif senestre au cours de la phase finale de la

58 collision oblique Trans-Hudsonienne. Les estimations thermobarométriques sur les assemblages M2-

$59 \mathrm{D} 2$ mettent en évidence un rééquilibrage à $4-5$ kbar et $750-825^{\circ} \mathrm{C}$. Le socle a donc été affecté entre

60 D1 et D2 par un épisode de décompression isotherme, ramenant au même niveau structural, la partie

61 nord-est la plus profonde de la zone d'étude et la zone de forage Wolly-McClean. Ces résultats

62 suggèrent que le socle affleurant au Nord-Est du bassin de l'Athabasca n'est pas l'analogue du socle

63 situé sous le bassin là où les enrichissements en uranium sont connus. Nous suggérons également que

64 les liquides silicatés enrichis en uranium, et produits au cours de l'épisode de fusion partielle M1-D1

65 dans la croute profonde, ont été transférés dans la croute moyenne, par le biais des zones de

66 cisaillement D2, et différenciés pour former les pegmatites enrichies en uranium.

67 Mots clés: Évolution tectono-métamorphique; Bassin de l'Athabasca; Orogénèse Trans-hudsonienne;

68 Zone de Transition Wollaston-Mudjatik; Uranium 


\section{Introduction}

The establishment of metallogenic models requires a thorough knowledge of the geological processes involved from source to ore deposit, including the formation of the elemental source and the mechanisms of extraction, transport, and deposition. Among them, the determination of the source and the potential mechanisms of concentration of the element of interest require a good knowledge of the geotectonic framework at the metallogenic province scale. The unconformity-type uranium deposits located in the Athabasca Basin (Saskatchewan, Canada; Fig. 1) are good examples for which the knowledge of geological processes that have affected both the Athabasca sandstone and the metamorphic basement prior to the uranium mineralization is critical for building a complete conceptual ore deposit model (Hoeve and Quirt 1984; Hecht and Cuney 2000; Jefferson et al. 2007b; Mercadier et al. 2010). Indeed, the great majority of the operating uranium mines and unmined deposits are located in the eastern part of the Athabasca Basin, where the Athabasca Group sediments unconformably overlie highly-deformed and partially-melted metasedimentary rocks and localized uranium-enriched pegmatites that belong to the Wollaston-Mudjatik Transition Zone (WMTZ). As defined by Annesley et al. (2005) and references therein (Figs.1, 2), the WMTZ marks a transitional change of structural style, metamorphism, magmatism, and lithology between the rocks of the Mudjatik Domain and the Wollaston Domain. The WMTZ was deformed and metamorphosed during the ca. 1.8 Ga continent-continent collision of the Trans-Hudson Orogen (THO) before the deposition of detrital sediments into the post-THO Athabasca Basin that began ca. 1.72-1.71 Ga (Cumming and Krstic 1992) and the subsequent formation and remobilization of uranium mineralization located at the unconformity, perched in the Athabasca sandstones, and/or within the basement, in the 1.6-1.3 Ga period (Hoeve and Quirt 1984, 1987; Jefferson et al. 2007a, b; and references therein). The close spatial relationship observed between Athabasca unconformity-type uranium mineralization and (1) the occurrence within the WMTZ of numerous uranium-enriched intrusive rocks (granitic pegmatites and granites), (2) the presence of graphite-bearing pelitic to psammopelitic gneisses (Thomas 1983; Annesley et al. 2005; Yeo and Delaney 2007; among others), and (3) brittle faults that reactivated Trans-Hudsonian ductile high strain zones (Hoeve et al. 1980), suggests that pre-Athabasca 
97

deformation, metamorphism, and partial melting may constitute a major first stage of uranium remobilization and elevation of uranium content that could be a critical factor necessary to obtain the world-class uranium deposits at or near the sub-Athabasca unconformity.

The geology of the Wollaston Group and its underlying Archean basement has been extensively studied over the last 20 years (Annesley and Madore 1994, 2002; Annesley et al. 1997a, 1997b, 2001, 2005; Madore and Annesley 1997a, 1997b; Madore et al. 1999b; Tran et al. 2001, 2003, 2008; Harper et al. 2005; Card et al. 2006; Yeo and Delaney 2007; McKechnie et al. 2012; and references therein). In this contribution, we present new structural and thermobarometric data carried out at a regional scale along and across strike of the WMTZ. We have used both outcrop observations and drill core material from the eastern part of the Athabasca Basin region where past and producing mines are located. The studied exposed basement is located along strike of the WMTZ and to the north-east of the active mines (Fig. 2). We propose a thermo-mechanical model for a portion of the WMTZ through examination of the evolution of deformation, kinematics, and metamorphic conditions across and along strike of the WMTZ. The main goal is to better understand the role of the basement in the formation of the unconformity-type uranium deposits of the Athabasca Basin. The fundamental question addressed in this contribution is: can the exposed basement to the north-east in the Wollaston Lake area be used as an analog for the basement below the Athabasca Group strata where the highgrade uranium deposits are located?

\section{Regional geological setting}

The rocks underlying the eastern part of the Athabasca Basin of northern Saskatchewan (Canada) comprise a complexly deformed and strongly metamorphosed crystalline basement, part of the Canadian Shield basement (Jefferson et al. 2007a). The western Canadian Shield of North America is underlain by Archean cratonic provinces, including the Churchill, Sask, and Superior provinces, separated by Paleoproterozoic orogens and major crustal shear zones (e.g. Hoffman 1988). The Trans-

Hudson Orogeny (THO) is the largest of these Paleoproterozoic orogens, separating the western Churchill Province and the Superior Province (Fig. 1). These basement rocks are unconformably 
overlain by the essentially undeformed upper Paleoproterozoic to Mesoproterozoic Athabasca Group. The region immediately above and below the Athabasca unconformity is the spatial location of the Athabasca unconformity-type uranium deposits.

\section{Athabasca Group}

The Athabasca Basin is a upper Paleoproterozoic to upper Mesoproterozoic intracratonic basin that is presently filled by up to $1500 \mathrm{~m}$ of preserved Athabasca Group strata, a series of quartz-rich dominantly arenitic sandstones. The deposition of the Athabasca Group sediments is inferred to have taken place between ca. 1720-1710 and 1500 Ma (Cumming and Krstic 1992; Rainbird et al., 2005; Rainbird and Davis 2007; Ramaekers et al. 2007). The Athabasca Group is made up of four major sedimentary sequences, separated by unconformities (Ramaekers et al. 2007), with most of the sediments being deposited by fluvial systems.

\section{Athabasca unconformity-type uranium mineralization}

The uranium deposits of the Athabasca Basin are of the unconformity type that is spatially-related to the sub-Athabasca unconformity. They are commonly associated with fractures and breccia zones in reactivated basement faults, typically rooted in graphitic pelitic gneiss, that cut the unconformity surface (Hoeve and Sibbald 1978; Hoeve and Quirt 1984; Jefferson et al. 2007a, b; Kyser and Cuney 2008). Uranium mineralization is variably sediment-hosted, situated in the sandstones immediately above the sub-Athabasca unconformity, or basement-hosted. Basement-hosted deposits include Rabbit Lake, Eagle Point, Cluff Lake, Sue C, and Millennium. Unconformity-hosted deposits such as Cigar Lake, Midwest, Shea Creek, and Collins Bay B occur at and slightly above the unconformity, while perched sandstone mineralization found at McClean Lake, Cigar Lake, Midwest, and Shea Creek are entirely hosted by sandstone and located several tens of meters above the unconformity (Jefferson et al., 2007). Some deposits contain mineralization in two or more of these locations (e.g. Shea Creek: basement, unconformity, perched; McArthur River: basement, unconformity; McClean Lake: unconformity, perched). Primary uranium mineralization appears to have occurred in the 1550-1590 Ma period (Fayek et al. 2002a, 2002b; Alexandre et al. 2009; among others). 
149

150

151

152

153

154

155

156

157

158

159

160

161

162

163

164

165

166

167

168

169

170

171

172

173

174

Significant amounts of clay mineral alteration of the host-rock alteration is associated with the uranium mineralization (Hoeve and Quirt 1984; Fayek and Kyser 1997; Quirt 2003; Jefferson et al. 2007). The alteration associated with the perched and unconformity mineralization locations is typical of the egress-style process (Hoeve and Quirt 1984; Quirt 2003; Jefferson et al. 2007a, b), with desilicification, illitization, chloritization, and variable bleaching/hematization phenomena being variously present. The alteration zones around the basement mineralization show similar features, but extend relatively small distances from mineralization, as compared to the sandstone alteration.

\section{Trans-Hudson Orogeny in central Canada}

The THO is a major Paleoproterozoic orogenic belt, bordered by the Archean Superior Province to the south and the Western Churchill Province to the north, that extends from Greenland to Baffin Island through central Canada (Manitoba and Saskatchewan), to the northcentral United States (Hoffman 1990). In this section, only the western part of the THO located in central Canada is discussed. The history of the THO began between ca. 1.92 and $1.89 \mathrm{Ga}$ with the closure of the Manikewan ocean that separated the Rae and Hearne Provinces, which are also referred as the composite Western Churchill Province, from the Superior craton margin (Stauffer 1984; Corrigan 2012; Corrigan et al. 2005, 2009). The closure of the ocean was associated with formation of juvenile crust consisting of island arcs, back arcs, ocean floor and plateau, and associated plutonic and sedimentary rocks, such as the Wollaston group sediments (see below) (e.g. Ansdell 2005; Corrigan et al. 2005). The accretion of this juvenile crust mostly to the composite Western Churchill Province occurred between 1.88 and 1.865 Ga and involved small Archean cratons, like the buried Sask Craton, in the north-west part of the THO (Hajnal et al. 2005). The final stage of the THO corresponds to the complete closure of the Manikewan ocean and the continental collision between the Hearne margin with the accreted juvenile arc complex and the northern Superior craton margin, between 1.83-1.80 Ga (Corrigan et al. 2009). The collision was followed by a late-collisional event from $1.80-1.76 \mathrm{Ga}$, characterized by a strike-slip deformation and emplacement of undeformed pegmatites and aplites (Bickford et al. 2005; Schneider et al. 2007; Culshaw and Clarke 2009). 
175 Work on the central Canadian part of the THO has benefited from the LITHOPROBE and the

176 EXTECH IV seismic-reflexion surveys to provide images of the crustal architecture of the western

177 part of the THO (Hajnal et al. 2005, 2007). From south-southeast to north-northwest, the THO

178 included two major domains: the Reindeer Zone and the Hearne Province; also referred as the Cree

179 Lake Zone by Corrigan et al. (2005) and earlier workers. The Reindeer Zone is an area represented by

180 juvenile Paleoproterozoic terranes formed during the closure of the Manikewan Ocean (Lewry and

181 Collerson 1990). It consists of three major belts that were accreted on the Hearne margin between 1.92

182 and 1.85Ga: the Flin Flon - Glennie Complex, the La Ronge - Lynn Lake Arcs, and the Rottenstone

183 Domain. It is beyond the scope of this contribution to give a detailed review of the geology of these

184 domains, which can be found in Corrigan et al. (2009) and Corrigan (2012). Although each domain

185 has distinct lithologies and deformation and metamorphic evolutions, they share several common

186 features. In summary, these domains consists of juvenile plutonic and volcanic arc-derived rocks and

187 associated sediments that were accreted to the Hearne margin, mostly via south-vergent thrust stacking

188 between 1.88 and $1.865 \mathrm{Ga}$ (Corrigan et al. 2009). The Rottenstone Domain, corresponding to the

189 westernmost domain of the Reindeer Zone, shows evidence of crustal thickening, coeval with granite

190 emplacement and partial melting, related to the collision stage (Culshaw and Clarke 2009). The final

191 convergence led to upright folding and development of steeply-dipping north-east trending foliation

192 and transpressive shear zones (Corrigan et al. 2005; Culshaw and Clarke 2009). Seismic profile S2b

193 (see Figure 7 in Corrigan et al. 2005) shows strong shallow north-west dipping reflectors in the

194 juvenile La Ronge Domain, consistent with structures observed at surface (Corrigan et al. 1999), as

195 well as the south-vergent thrust stacking kinematics. The more seismically-transparent upper crust of

196 the Rottenstone is consistent with the steep fabrics and partial melting developed during the post-

197 accretion collision (Corrigan et al. 2005).

198 The inner part of the western Reindeer Zone overlies the buried Sask Craton that has been imaged

199 seismically (Hajnal et al. 2005). On the seismic profile, the Sask Craton corresponds to a low-

200 reflectivity domain. Although most of the craton is located at middle to lower crustal level, it can be

201 observed within three small windows in the Glennie Domain. The Sask Craton mainly consists of

202 Neoarchean felsic rocks (2.4-2.5 Ga) and Archean orthogneiss (3.1-2.8 Ga) (Rayner et al. 2005). The 
203

204

205

206

207

208

209

210

211

212

213

214

215

216

217

218

219

220

221

222

223

224

225

226

227

228

Sask Craton is interpreted to be a microcontinent initially located between the Superior Craton and the composite Western Churchill Province prior to its accretion to the Reindeer Zone and Hearne margin (Corrigan et al. 2005).

The present-day boundary between the Reindeer Zone and the Archean Hearne margin is characterized by the presence of the Wathaman Batholith, a major continental-arc complex in the northwest (Fumerton et al. 1984) that was emplaced into Archean rocks of the Hearne margin (Peter Lake Domain) between 1.86-1.85 Ga, and in the south-east by the previously-accreted Paleoproterozoic Reindeer Zone (La Ronge domain) (Lewry et al. 1994; Kyser and Stauffer 1995; Corrigan et al. 2005). Corrigan et al. (2009) suggested that the Wathaman Batholith masks the suture between accreted juvenile terranes and the Hearne craton margin. The intrusive contacts have been, for the most part, strongly reworked to produce high strain zones like the Needle Falls shear zone that separates the Peter Lake Domain from the Wathaman batholith.

The Hearne craton margin consists of Archean rocks and their Paleoproterozoic passive margin cover material that have been reworked during mostly the collision stage of the THO. In the studied area, the region in which Archean basement is dominant is referred as the Mudjatik Domain, while the region containing a large amount of supracrustal Paleoproterozoic material corresponds to the Wollaston Domain. The rocks of both domains, separated by the north-east-trending Wollaston Mudjatik Transition Zone (Fig.1), have been subjected to a complex polyphased deformation and metamorphism accompanied by metaluminous to peraluminous magmatism during the ca. $1.8 \mathrm{Ga}$ continent-continent collision of the THO (Lewry and Sibbald 1977, 1980; Madore and Annesley 1993; Annesley et al. 1997a, 1997b, 1999, 2005; Madore et al. 1999a, 1999b; Orrell et al. 1999).

\section{Wollaston and Mudjatik Domains}

The Wollaston Domain is a northeast-trending fold and thrust belt composed of Paleoproterozoic Wollaston Group metasediments overlying Archean felsic (tonalitic to granitic) gneisses, whereas the Mudjatik Domain is a northeast-trending, shear-bounded belt consisting mainly of Archean felsic gneisses with subordinate supracrustal Wollaston Group metasediments (Annesley et al., 1997). 


\section{Lithological units}

The Archean basement that is exposed mainly in the Mudjatik domain (MD) and within structural domes in the Wollaston domain (WD) consists of felsic gneisses intruded by Neoarchean granites (2.64 -2.58 Ga) (Ray 1978, 1979; Annesley et al. 1997, 1999; Harper et al. 2005). U-Pb zircon age determinations have indicated that the oldest Archean granitoid gneiss was emplaced at ca.3.0 Ga (Orrell et al. 1999), but the majority of felsic gneisses are in the range 2.73 to $2.70 \mathrm{Ga}$ (Annesley et al. 1997; Harper and van Breemen, 2004).

The Paleoproterozoic supracrustal Wollaston Group, which overlies the Archean basement, has been studied in detail by Tran (2001), Annesley et al. (2005), Harper et al. (2005a, 2006), and Yeo and Delaney (2007), and Tran et al. (2008), who defined the lithostratigraphic sequence. Although individual studies show some differences, they all conclude that the Wollaston Group can be divided into three main sequences: Lower, Middle, and Upper. The age of deposition of the Wollaston Group sequence ranges between 2.1 and ca. $1.85 \mathrm{Ga}$ (Tran et al. 2008). The minimum age of deposition of this sequence is given by zircon metamorphic ages of $1.86 \mathrm{Ga}$ and the intrusion of the $1.86 \mathrm{Ga}$ Wathaman Batholith into the supracrustal Wollaston Group (crystallization age, between 1.865 and 1.855Ga; Van Schmus et al. 1987; Meyer et al. 1992). In the portion of the WMTZ that is discussed in this contribution, only the Lower and Middle sequences are exposed.

The Lower sequence consists of quartzite, amphibolite (derived from mafic igneous rocks), and rare "banded iron formation" (Harper et al. 2005). The Quartzite-Amphibolite succession (QA) has been observed in direct contact with the Archean basement and therefore is interpreted as the base of the Wollaston Group (Harper et al. 2005a, 2006, 2007). However, the QA succession has also been interpreted to be an equivalent to the Hidden Bay Assemblage (HBA) in the Rabbit Lake area, which is located stratigraphically above the much of the Wollaston Group (Sibbald et al. 1977; Ray 1978; Yeo and Delaney 2007). This apparent contradiction can be explained either tectonically and/or by lithofacies changes across a continental margin.

In the Middle sequence, two main lithological units have been distinguished: 1) a basal unit that consists of quartzo-feldspathic psammitic to pelitic gneiss, representing $70-80 \%$ of the metasedimentary rocks occurring in the WD (Annesley et al. 2005), with garnet, cordierite, sillimanite, 
257

258

259

260

261

262

263

264

265

266

267

268

269

270

271

272

273

274

275

276

277

278

279

280

281

282

283

Ti-rich biotite, and local enrichments in graphite; and 2) calc-silicate rocks. The Middle sequence (equivalent to sequence II of Tran 2001) contains a significant amount of ca. 1.92-1.88 Ga detrital zircon, derived from juvenile volcanic terranes, indicating that the Middle sequence was deposited after $1.92 \mathrm{Ga}$ (Tran et al. 2008).

\section{Metamorphism and deformation}

Preservation of Archean deformation and metamorphic features in the Mudjatik and Wollaston domains is poor, either because of pre-Hudsonian structures and metamorphic assemblages have been strongly to completely obliterated by the THO overprint, or because they have not been recognized as Archean. However, Annesley and Madore $(1991,1994)$ suggested that the Archean gneisses preserve remnants of an early granulite facies metamorphism that is poorly constrained in terms of timing and physical conditions because of subsequent re-equilibration during the THO and a corresponding lack of thermobarometric data from the Archean granulite facies mineral assemblages.

Hudsonian metamorphism features in the basement and the supracrustal rocks are well preserved. These rocks were affected by a complex, polyphased deformation, high-grade metamorphism and associated partial melting, and emplacement of plutonic rocks during the final stage of the THO and the late-collisional event at 1.83 to 1.76. (Lewry and Sibbald 1980; Chiarenzelli et al. 1998; Annesley et al. 2001; Annesley et al. 2005; Mercadier et al. 2013). P-T conditions associated with the peak metamorphism of the Hudsonian orogeny, between 1.83 and $1.80 \mathrm{Ga}$, have been estimated at about $800^{\circ} \mathrm{C}$ and $8 \mathrm{kbar}(1 \mathrm{kbar}=100 \mathrm{MPa})$ (Annesley et al. 2005). The beginning of the exhumation of the basement at about 1.82-1.81 corresponds to the peak thermal assemblage (garnet-cordierite-sillimanite) and has been estimated at about $820^{\circ} \mathrm{C}$ and $7.5 \mathrm{kbar}$ by Annesley et al. (2005). This event is coeval with partial melting and emplacement of most of the leucogranites and granitic pegmatites (Annesley et al. 2005; McKechnie et al. 2012a, 2012b). A second episode of significant high-T retrograde metamorphism has been documented at ca. 1.77 Ga by Schneider et al. (2007) and McKeough et al. (2013). This event was followed by exhumation and cooling to ca. 1.72 Ga (Annesley et al. 2005), down to an estimated pressure of about $2 \mathrm{kbar}$ and temperature of $350^{\circ}$ to $400^{\circ} \mathrm{C}$ ( Mercadier et al. 2010). 

periods of ductile deformation with three related periods of folding (Table 1). (1) The $\mathrm{D}_{\mathrm{P} 1}$ event produced the oldest foliation ( $\mathrm{S}_{\mathrm{P} 1}$ regional axial planar foliation) in the Wollaston Group metasediments and is associated with thrusting and rare intrafolial folds $\left(\mathrm{F}_{\mathrm{P} 1}\right) .(2)$ A second penetrative ductile deformation event, $\mathrm{D}_{\mathrm{P} 2}$, is associated with north-east-trending upright to northwest overturned folds $\left(\mathrm{F}_{\mathrm{P} 2}\right)$, the development of a steeply-dipping north-east-trending foliation that is axial planar to the $\mathrm{F}_{\mathrm{P} 2}$ folds, and steep sinistral-strike slip-shear zones. The $\mathrm{D}_{\mathrm{P} 2}$ deformation gave rise to the dominant northeast structural grain of the Wollaston Domain, in particular, and Mudjatik Domain. This second stage of deformation is interpreted to be the result of oblique collision with a sinistral transpressive component at 1.82-1.80 Ga (Annesley et al. 2005).

(3) The third ductile deformation event $\left(\mathrm{D}_{\mathrm{P} 3}\right)$ resulted in the formation of broad open folds with axial planes striking mainly northwesterly, as well as amphibolite-facies shear zones with a dextral strike-slip component. Evidence for ductile-brittle transition faulting and brittle faulting is common in the Wollaston and Mudjatik Domains, but discussion on this topic is beyond the scope of this contribution.

\section{Significance of the Wollaston-Mudjatik Transition Zone}

The nature and significance of the WMTZ is still enigmatic, even after several decades of research. Annesley and Madore (1994) observed that the Wollaston-Mudjatik boundary, in the Wollaston Lake area, marks an abrupt change of lithology and structural style. However, to the southwest, Annesley et al (2005, and references therein), Gyorfi et al (2007), Hajnal et al (2010), among others, showed that this domain boundary is a highly heterogeneous transition zone both across and along strike.

The WMTZ appears to be both a deformation and thermotectonic front, which may exert first-order controls on subsequent brittle-regime fluid flow, heat flow, alteration, and mineralization. Annesley et al. (2005) proposed that brittle reactivation of structures within the WMTZ, and consequent heat and fluid flow along them, controlled the location of the unconformity-type uranium deposits. relationships seen in drill core, and is based on lithological changes in the Archean basement and 
311 Wollaston Group (Annesley et al. 2005). The WMTZ was also clearly outlined by the available

312 aeromagnetic data of the Archean-Paleoproterozoic basement that highlight a significant aeromagnetic

313 low which is known to reflect an increased abundance of pelitic and semi-pelitic gneiss units in the

314 basement (Li et al. 2013).

315 The tectonic concept presented by Annesley et al. (2005) also accommodates an increase in vertical 316 uplift and exposure of deeper crustal rocks westward across the WMTZ to the MD and is compatible

317 with the presence of only a thin veneer of supracrustal Wollaston Group in the MD, as suggested by

318 Lewry and Sibbald $(1977,1980)$.

\section{Structural analysis}

320

321

322

323

324

325

326

327

328

329

330

331

332

333

334

335

\section{Bulk architecture}

Available geological maps of the area of interest published by the Saskatchewan Geological Survey (Wollaston Lake area, NTS area 64L-6 -7 -10-11 -15; Harper et al. 2005a, 2005b; Card et al. 2006) show that the overall finite strain pattern consists of NE-SW-trending elongated dome-and-basin structures. The cores of the domes consist of migmatitic orthogneiss and granitoids and are surrounded by supracrustal rocks, mainly paragneiss, which form the synformal structure (Figs. 2, 3, 4). In addition, the dome-and-basin structures are affected by NE-SW-trending, sub-vertical high-strain zones ranging from kilometer to meter scale. This bulk architecture of the WMTZ is interpreted to be the result of the superposition of two phases of TransHudson ductile deformation, D1 and D2, that can be observed at all scales, from outcrop to regional scale. Macro- and micro-structures related to these two deformation events have been characterized combining outcrop observations with compiled published maps. The early ductile finite strain pattern has been reworked by late brittle deformation, corresponding to the development of the north-trending Tabbernor fault system (grey line in Figs. 2, 3, 4). The ductile and brittle deformation features were subsequently by the emplacement of the $1.27 \mathrm{Ga}$ northwest-trending Mackenzie diabase dykes that crosscut all the structures (Figs. 2, 3, 4; Le Cheminant and Heaman 1989; Quirt, 1993). 


\section{D1 deformation}

The D1 deformation is characterized by the development of a S1 foliation that affects both the Archean basement and Paleoproterozoic supracrustal Wollaston Group (Figs. 3, 5). In the WMTZ, S1 foliation in the Archean basement has been best observed and characterized in the western and eastern side of the WMTZ, at Crozier and Shaganappie Islands, respectively (Figs. 3, 5a, 5b, 5c). S1 structures in Archean basement have also been inferred in the Mudjatik Domain, west of Fife Island, based on geophysical and geological data. In the Wollaston Group supracrustal rocks, S1 is more rarely observed and it is best preserved west of Lejour Island where the QA succession of the Lower sequence is exposed. S1 can also be observed in the basal migmatitic gneiss of the Middle sequence throughout the WMTZ, as meter- to kilometer-scale microlithons (Fig.5d).

In the Archean basement, the S1 foliation corresponds to a gneissic foliation with quartzo-feldspathic layers alternating with biotite ( \pm amphibole)-rich layers. The foliation is also well defined by centimeter- to decimeter-scale, fine-grained to pegmatitic leucosomes (Figs. 5a, 5c). However, this S1 foliation could be also an Archean penetrative foliation overprinted by TransHudson structures. In the migmatitic gneisses of the Wollaston Group Middle sequence, the S1 foliation, synchronous with partial melting, is defined by the alignment of feldspar, quartz, and biotite \pm sillimanite, the presence of millimeter- to centimeter-wide leucosomes (Figs. 5d, 5e), and by the original sedimentary bedding which is locally preserved (Fig. 5f).

In the domains where the $\mathrm{S} 1$ foliation is best preserved, $\mathrm{S} 1$ corresponds to a sub-horizontal to moderately-dipping planar fabric that strikes between $\mathrm{N} 080^{\circ}$ to $\mathrm{N} 120^{\circ}$ (Figs. 5c, 5e, 8a, 8b, 9a, 9b). However, in most cases, the S1 foliation is folded at decimeter to meter scales by open F2 folds with steeply-dipping axial planes (see below) that still allows the definition of an enveloping surface approximately oriented east-west that is in good agreement with the preserved S1 orientations. Orientations of preserved S1 foliation and enveloping surfaces in the Wollaston Lake and Cochrane River map-areas define a north-south-striking girdle with sub-horizontal $\beta$-axes consistent with the presence of post-S1 folds with steeply dipping east-west axial planes and sub-horizontal axes (Figs. $8 \mathrm{c}, 9 \mathrm{c})$. 
363

364

365

366

367

368

369

370

371

372

373

374

375

376

377

378

379

380

381

382

383

384

385

386

387

388

Because neither clear stretching lineations nor kinematic indicators have been observed to be associated with the $\mathrm{S} 1$ foliation, it is not possible to make any interpretation of the $\mathrm{D} 1$ tectonic regime.

\section{D2 deformation}

Within the studied WMTZ, D1-related structures are overprinted by a D2 deformation that affects both the Archean basement and the Paleoproterozoic Wollaston Group. D2 deformation is strongly heterogeneous and localized in the migmatitic paragneiss of the Wollaston Middle sequence, where it forms vertical high strain zones, mostly localized at the contact between Archean gneiss and Wollaston Group metasediments. The overall N40 ${ }^{\circ}$-trending orientation of the WMTZ is related to this D2 deformation (Figs. 2, 3, 4, 8a, 9a).

In the Archean basement, the S2 foliation corresponds either to a transposed gneissic S1 foliation (Fig. $5 b$ ) or to a newly-formed penetrative foliation (Figs. 6a, 6c, 6d). In the migmatitic paragneiss of the Wollaston Group, the S2 foliation is defined mostly by the alignment of sillimanite, biotite, and cordierite, and also by the presence of millimeter-to centimeter-wide leucosomes (Figs. 6f, 11). This deformation is contemporaneous with partial melting and significant melt transfer, as suggested by the occurrence of numerous metatexite intervals (Fig.6f) and pegmatites oriented parallel to the D2 structures observed in both Archean basement and the Wollaston domain (Figs. 6b, 6d).

Although D2 deformation is intense, stretching lineations are not easily recognized, suggesting that the flattening component of the D2 deformation is important. L2 stretching lineation is best observed in the D2 high strain zone present in the northeastern part of the Wollaston Lake study area and is defined by the preferred orientation of quartzofeldspathic assemblages in psammo-pelitic gneisses. The L2 stretching lineation plunges from $\mathrm{N} 10^{\circ}$ to $\mathrm{N} 40^{\circ}$ in both NE and $\mathrm{SW}$ directions (Figs. 8c, 8d, 9c, 9d). L2 lineations are collinear with F2 fold axes and tend to show the same dispersion, suggesting that fold axes have been passively rotated towards $\mathrm{N} 40^{\circ}$ and $\mathrm{N} 220^{\circ}$ during the $\mathrm{D} 2$ sinistral progressive deformation (Figs. 8c, 8d ,9c, 9d). In pelitic gneiss, leucosomes are boudinaged in both the $\mathrm{X}$ and $\mathrm{Y}$ directions of the finite strain ellipsoid, evidencing a strong component of flattening during D2 deformation. 
389

390

391

392

393

394

395

396

397

398

399

400

401

402

403

404

405

406

407

408

409

410

411

412

413

414

415

The S1/S2 relationships observed at the scale of the Wollaston region (Fig. 3) and on the outcrop scale (Fig. 5c) are also consistent with finite sinistral shearing. In D2 high strain zones, such as the western side of the WMTZ between Kendel Island and Lejour Island, east of Shaganappie Island, or between samples 13W042 and 13W022C in the Cochrane River study area, D2 deformation is penetrative, with the development of a S2 foliation with a mean direction of $\mathrm{N} 40^{\circ} / 90^{\circ}$. This S2 foliation also corresponds to shear plane $\mathrm{C} 2$, and is referred to as $\mathrm{S} 2 / \mathrm{C} 2$ foliation. S1 structures in D2 high strain zones are almost completely overprinted or transposed into the S2/C2 foliation. The S2/C2 foliation is locally affected by sinistral vertical C2' shear bands oriented N10-30 (Fig.7). Pegmatites (Fig.7a) and leucosomes (Figs.7b, 7c) are commonly located along these C2' shear bands. Ductile C2' shear bands have been reactivated under brittle conditions suggesting that the D2 deformation persisted or was reactivated at lower temperature (Fig.7d).

In D2 low strain zones, D2 deformation is characterized by open to tight F2 folds with vertical axial planes and axis with variable trend and plunge (Figs. 3, 8d, 9d). Stereonet plots that summarize the orientation of F2 axis folds, from the Wollaston Lake and Cochrane River areas, show a dispersion of fold axes from $\mathrm{N} 80^{\circ}$ to $\mathrm{N} 40^{\circ}$ (Figs. 8d, 9d). Axial planes of $\mathrm{F} 2$ folds are locally related to the development of cordierite (Fig. 5f), leucosome development (Fig. 6f), and the emplacement of pegmatites (Figs. 5b, 6d), showing that D2 deformation occurred at LP-HT conditions.

Overall, the D2 deformation at the origin of the northeast trend of the WMTZ is characterized by the development of penetrative steeply dipping S2/C2 and C2' structures that were formed progressively in the same sinistral transpressional regime. Figure 10 summarizes the progressive ductile strain evolution: The first stage corresponds to the formation of a shallow dipping S1 foliation. The onset of D2 deformation corresponds to the folding of S1 foliation by F2 folds with east-west vertical axial plane and shallow plunge. F2 fold axes are progressively reoriented to a $\mathrm{N} 40^{\circ}$ direction that corresponds to the anti-clockwise rotation of pre-existing S1 foliation and early East-West oriented F2 folds (see above) towards a $\mathrm{N} 40^{\circ}$-direction. This evolution of $\mathrm{F} 2$ fold direction is interpreted to be the effect of the D2 sinistral shearing. Furthermore, the progressive movement toward vertical of the preexisting F2 hinges is also directly related to the sinistral shearing that tends to produce curviplanar 
drag folds (Choukroune 1995). D2 deformation is partitioned between high strain zones and low strain zones where early F2 folds and S1 foliation are preserved. The last stage of D2 deformation corresponds to the development of many localized sinistral vertical C2' shear bands striking N10$\mathrm{N} 20^{\circ}$ in high strain zones. In this interpretation, the D2 heterogeneous and progressive deformation is related to a bulk sinistral transpressive regime ranging from ductile to brittle conditions.

\section{Petrology and Thermobarometry}

The structural analysis of the northern part of the Wollaston Lake study area shows that the finite strain pattern resulted from the superposition of D1 and D2 deformations, which are coeval with partial melting. To unravel the entire Trans-Hudsonian tectono-metamorphic evolution, it is critical to constrain the P-T conditions of each deformation phase. This task has been performed using forward thermodynamic modeling of phase relations via the pseudosection approach (Fig. 14; Worley and Powell 2000). The studied and modeled samples come from the Cochrane River area, the northern shore of Wollaston Lake, and from drill cores from the Wolly-McClean exploration drilling project within the Athabasca Basin (Fig.2). This wide spatial distribution of samples allows discussion of the variations in pressure and temperature related to the D1 and D2 foliations. The location of the three studied sites allows the determination of whether (1) they belonged to the same structural level during the D1 deformation event, and (2) the D2 steeply-dipping NE-trending S2/C2 foliation defining the WMTZ is a major metamorphic boundary between the Mudjatik and the Wollaston Domains. Therefore, the structural setting of each studied sample was established after field observations and structural measurements. To depict potential variations in $\mathrm{P}-\mathrm{T}$ conditions $(\Delta \mathrm{P}$ and $\Delta \mathrm{T})$, only samples of partially-melted aluminous pelitic gneisses belonging to the Wollaston Group were selected and the same thermobarometrical approach (see below) was applied to all samples so that uncertainties related to the thermodynamic modeling (thermodynamic database of end-members and solid solution models) are minimized. This approach is similar to the $\Delta \mathrm{P}-\mathrm{T}$ thermobarometry approach developed by Worley and Powell (2000). 
441 Sample petrography and mineral chemistry

442

443

444

445

446

447

448

449

450

451

452

453

454

455

456

457

458

459

460

461

462

463

464

465

466

467

Most of the studied migmatitic paragneisses contain quartz, feldspar, plagioclase, biotite, garnet, cordierite, and sillimanite. Tables 2 and 3 show the sample labels, and geographic location, as well as mineral chemical compositions of garnet and cordierite used in the thermobarometric estimations.

Garnet is ubiquitous in both melanosomes and leucosomes, and in leucosomes it occurs as porphyroblasts that may reach several centimeters in width (sample 12W008; Figs. 11c, 11d). Most of the garnets are relatively inclusion-free, with the exception of rounded quartz, fibrolitic sillimanite, and small euhedral graphite crystals. Although garnet compositions vary between samples, the analyses show that each garnet is a limited range of zoning with a dominant pyrope-almandine composition $\left(\mathrm{X}_{\mathrm{Alm}}: 0.71-0.86 \mathrm{X}_{\mathrm{Prp}}: 0.10-0.25\right)$, with minimal $\mathrm{X}_{\mathrm{Grs}}(0.015-0.034)$ and with insignificant spessartine content (Fig.13 and Table 3). Where zoned, the variations are restricted to a few tens of microns near the rim and display a decrease in the $\mathrm{Fe} / \mathrm{Fe}+\mathrm{Mg}$ molar ratio. Cordierite is present in most of the metapelitic and metapsammopelitic rocks in association with garnet, as clear blue millimeter- to centimeter-size grains (sample 12W078; Fig. 11b). However in the Wolly-McClean drilling area, cordierite is almost entirely retrogressed to chlorite and clays, except for the sample TC33 located in the far north of the property. In the other areas, cordierite occurs either as porphyroblasts or as a phase that mantles garnet in pressure shadows, suggesting that it was produced at the expense of garnet (Figs. 12b, 12c). Cordierite porphyroblasts are elongated parallel to the S1 and S2 foliations and contain sillimanite needles, small euhedral graphite crystals, and locally spinel (sample 12W023A; Fig. 12d). The $\mathrm{X}_{\mathrm{Mg}}$ (i.e., $\mathrm{Mg} /(\mathrm{Fe}+\mathrm{Mg})$ ) of all analyzed cordierite varies from 0.46 to 0.67 (Table 3). In the Wollaston Lake area, plagioclase has an oligoclase composition $(\mathrm{An}=20 \%)$ while in samples from the Cochrane River and the Wolly-McClean exploration drilling project, plagioclase is more calcic, with an anorthite content up to $42 \%$ (Table 3 ).K-feldspar has a finely microperthitic texture and locally contains quartz inclusions. Albite content in the K-feldspar does not exceed $19 \%$.

The D1 or D2 foliations in the paragneiss are defined by the preferred orientation of large amounts of biotite and prismatic sillimanite (Figs.11, 12). Biotite compositions vary in $\mathrm{X}_{\mathrm{Mg}}$ from 0.30 to 0.60 . In 
468 the southern part of the drilling project, the retrogression event is characterized by the crystallization

469 of large flakes of graphite that define, with the biotite, the S2 foliation (Figs.12e, 12f). Accessory

470 minerals are represented by pyrite, ilmenite, rutile, hematite, spinel, anatase, monazite, and zircon.

471 The petrological study shows that the mineralogical assemblages associated with D1 and D2 structures

472 cannot be distinguished. This is mostly due to the overprint of the D2 deformation, even in D2 low-

473 strain zones, where a S1 foliation is preserved. Both D1 and D2 structures are characterized by a

474 metamorphic assemblage that consists of garnet, cordierite, sillimanite, biotite, and melt. The

475 common observations of garnet porphyroblasts in leucosomes, defining either the S1 or S2 foliation,

476 suggest that garnet is a peritectic phase produced via the biotite-dehydration melting reaction (1a).

$$
\mathrm{Bt}+\mathrm{Sil}+\mathrm{Pl}+\mathrm{Qtz}=\mathrm{Grt}+\text { melt }
$$

478 Two textural types of cordierite are observed. Cordierite occurs as elongated porphyroblasts,

479 containing small needles of sillimanite, that are parallel to the foliation. This cordierite is interpreted

480 as a peak metamorphic phase produced in conjunction with garnet by biotite-dehydration melting,

481 through reaction $(1 b)$,

The second type of cordierite forms moats surrounding garnet and is interpreted as a retrograde phase consistent with the reaction (2).

Locally, in quartz-undersaturated domains, spinel is observed in equilibrium with the retrograde cordierite, suggesting that reaction (3) is applicable.

$$
\mathrm{Grt}+\mathrm{Sil}=\mathrm{Crd}+\mathrm{Spl}+\mathrm{melt}
$$
contemporaneous with D2 deformation. 
491

492

493

494

495

496

497

498

499

500

501

502

503

504

505

506

507

508

509

510

511

512

513

514

515

516

517

\section{Thermobarometric modeling}

Thermobarometric estimations have been performed via forward modeling using the Perple_X collection of programs (version 6.6.7). The approach consists in computing the stability field of equilibrium mineral assemblages for a given bulk-rock composition for any pressure and temperature (phase diagram section or pseudosections).

All pseudosections have been computed in the TiNaCaKFMASH system with the thermodynamic data of Holland and Powell (1998, revised in 2003). Phases involved in the modeling are Biotite, Garnet, Cordierite, White Mica, Plagioclase, K-feldspar, Melt, Staurolite, sillimanite, kyanite, ilmenite, rutile, and quartz, with the minerals with an initial upper case letter being modelled as solid solutions. The bulk compositions and the representative mineral composition used are presented in Tables 2 and 3, respectively.

The amount of water used in the pseudosection calculations is a critical variable that cannot be deciphered solely on the basis of bulk composition analyses. The amount of water involved at high temperature is determined via a series of $\mathrm{T}-\mathrm{MH}_{2} \mathrm{O}$ pseudosections $\left(\mathrm{MH}_{2} \mathrm{O}\right.$ stands for the amount of water in the bulk composition), such that the solidus is water-saturated at $5 \mathrm{kbar}(1 \mathrm{kbar}=100 \mathrm{MPa})$. Although graphite is a common accessory phase in most of the studied migmatitic metapelites, the role of $\mathrm{CO}_{2}$ on the phase relations has not been considered. When graphite is present, carbon-bearing species dissolve in the C-O-H fluid and therefore lower the activity of water in the fluid and influence the P-T location of equilibrium (Chu and Ague 2013). However, the temperature change on most meltbearing equilibria at pressures in the 4 to $9 \mathrm{kbar}$ range is less than $15^{\circ} \mathrm{C}$ (Chu and Ague 2013). This is in the same order of magnitude or smaller than the potential kinetic effects (Pattison et al. 2010; Gaidies et al. 2011) and uncertainties propagated from the thermodynamic data (Powell and Holland 2008).

Three representative phase diagram sections from three metapelites, one from each of the WollyMcClean exploration drilling project (core sample TC33), Wollaston Lake (12W008), and Cochrane River (13W23A) are presented in Figures 14a, 14 c, 14e. Although these phase diagrams have been computed with distinct and different bulk compositions, they share similar features: (1) a $\mathrm{H}_{2} \mathrm{O}-$ 
518

519

520

521

522

523

524

525

526

527

528

529

530

531

532

533

534

535

536

537

538

539

540

541

542

543

544

saturated solidus at $660-690^{\circ} \mathrm{C},(2)$ a large stability field, corresponding to the peak metamorphic assemblage, consisting of biotite, garnet, sillimanite, melt, \pm rutile or ilmenite, between $\sim 700$ and $850^{\circ} \mathrm{C}$ and $\mathrm{P}>5-6 \mathrm{kbar}$, and (3) cordierite-bearing assemblages that are stable at pressures lower than $5 \mathrm{kbar}$. The location of the solidus, garnet-in reaction, and cordierite-in reaction, computed for all samples in each studied area, are presented in Figures 14 b, 14d, and 14f. Although the bulk sample compositions vary, it appears that the locations of these three major phase boundaries are very consistent between samples.

To refine the calculated metamorphic conditions experienced by the pelitic gneisses, the phase diagrams have been contoured for grossular content in garnet, which is the component that will be the least modified by retrograde exchange reactions (Pattison and Bégin 1994), and $\mathrm{X}_{\mathrm{Mg}}$ in cordierite (Fig. 14). The grossular content isopleths are P-dependent, when in equilibrium with biotite, sillimanite, and melt, and constitute a good geobarometer (Fig.14).

Thermobarometric estimations on migmatitic paragneiss from the three studied areas (Cochrane River, Wollaston Lake, and Wolly-McClean drilling area) show that peak metamorphic conditions (M1) recorded by the maximum grossular content in garnet range in pressure from 5 to $10 \mathrm{kbar}$ and in temperature from 700 to $850^{\circ} \mathrm{C}$. These conditions are consistent with those reported by previous workers in the Wollaston domain (Tran 2001; Harper et al. 2005a) and are interpreted as the P-T conditions of the D1 deformation event. However, it appears that there is a pressure gradient from north-east to south-west, perpendicular to the trend of the S1 foliation. The highest pressures of $\sim 7-10$ kbar are preserved in the Cochrane River and Wollaston Lake area, while samples from the WollyMcClean drill core area record pressures that do not exceed 6.5 kbar (Fig.14).

One sample from the Cochrane River area (13W022C; Fig.14e) gives thermobarometric estimation with a pressure slightly above $10 \mathrm{kbar}$ in the kyanite stability field. This result is consistent with the occurrence of kyanite, reported by Card et al. (2006) from the Charcoal Lake area that is located just $15 \mathrm{~km}$ to the east of the Cochrane River study area.

The peak metamorphic event M1 is followed by a decompression, which led to the formation of cordierite-bearing assemblages in all the studied areas. However, the predominance of cordierite in D2 
545 high strain zones and the local observation of cordierite aligned with F2 axial planes (Fig. 5f) suggest

546 that the crystallization of cordierite was contemporaneous with the D2 event.

547 Based on the $\mathrm{X}_{\mathrm{Mg}}$ contents of cordierite, the contoured phase diagram sections show that all migmatitic

548 paragneiss samples were equilibrated during a M2-D2 event at about 4.5 to $5.5 \mathrm{kbar}$ and $700-850^{\circ} \mathrm{C}$ in

549 the stability field of garnet and cordierite. These retrograde P-T conditions are homogeneous

550 throughout the studied area and suggest that the basement was affected by a M2-D2 differential

551 decompression from $\sim 5 \mathrm{kbar}$ in the north (from $\sim 10 \mathrm{kbar}$ to $\sim 5 \mathrm{kbar}$ in the Cochrane River area) to less

552 than $1 \mathrm{kbar}$ in the south (from $\sim 6 \mathrm{kbar}$ to $\sim 5 \mathrm{kbar}$ in the Wolly-McClean exploration drilling project).

553 In most of the studied samples, the re-equilibration at lower pressure of the M1 garnet-bearing

554 assemblage during the M2 event does not induce a significant transformation of garnet into cordierite,

555 except for a few cordierite moats around garnet. The preservation of large amounts of garnet during

556 the beginning of the M2 decompression is due to the high slope (almost vertical) of the isopleths of the

557 modal proportions of garnet (Fig.S1. ${ }^{1}$ ). This also suggests that the M2 decompression was near-

558 isothermal ca. $750^{\circ} \mathrm{C}$.

\section{Discussion}

560 The Athabasca Basin hosts the world's largest known high-grade unconformity-type uranium deposits, 561 including the McArthur River, McClean Lake (Sue deposits), Key Lake, Shea Creek, Triple R, Rabbit

562 Lake, Eagle Point, and Cigar Lake deposits (Fig.1). A common feature of unconformity-type uranium

563 deposits located in the eastern portion of the Athabasca Basin is their close spatial association with the

564 WMTZ and associated reactivated basement faults intersecting the unconformity surface (Jefferson et

565 al. 2007a). However, significant gaps remain in our understanding of the role of the basement in the

566 formation of the Athabasca unconformity-type uranium deposits. Among these gaps is the

567 determination of the tectono-metamorphic history that led to the formation of the WMTZ and its

568 geodynamic significance. Here, we discuss the role of this tectono-metamorphic history on the early

$1 \quad$ Supplementary data 
569

570

571

572

573

574

575

576

577

578

579

580

581

582

583

584

585

586

587

588

589

590

591

592

593

594

595

concentration and/or redistribution of uranium in the crust prior to the deposition of the Athabasca Group at ca. $1.7 \mathrm{Ga}$.

\section{M1-D1 event: peak metamorphic conditions of burial and significance of the M1-D1} pressure gradient

The first regional tectono-metamorphic event M1-D1 is characterized by granulite-facies assemblages and partial melting, and is associated with the development of a shallow-dipping S1 foliation that trends $\sim$ east-west. Thermobarometric estimates acquired from migmatitic paragneiss reveal a significant change in peak pressure from up to $10 \mathrm{kbar}(1 \mathrm{kbar}=100 \mathrm{MPa})$ in the Cochrane River area, to 8-9 kbar in the Wollaston Lake area, and down to 5-6 kbar in the Wolly-McClean exploration project area (Fig. 15). This north-eastwards increase in peak pressure of about $\sim 5 \mathrm{kbar}$, is consistent with the observation of kyanite in the Charcoal Lake area (north-east of Cochrane River; Fig. 15; Card et al. 2006), that could imply pressures higher than $10 \mathrm{kbar}$ at $800^{\circ} \mathrm{C}$.

We suggest that the M1 regional metamorphic event and associated partial melting is related to the burial of the supracrustal Wollaston Group rocks to a maximum depth of $\sim 35 \mathrm{~km}$ and temperature of $750-825^{\circ} \mathrm{C}$. This occurred through nappe stacking and under-thrusting during a north-south shortening that drove the development of a shallow-dipping S1 foliation.

Although D1 thrust faults have not been clearly observed in the field due to the intense D2 reworking, this geometry is consistent with the occurrence of a strong north-west-dipping seismic reflector observed in the present-day middle-crust (between $\sim 12$ and $22 \mathrm{~km}$ ), along the seismic reflection profile from the McArthur River mine area, south of the study area (Fig. 1), during the EXTECH IV project (Hajnal et al. 2010). This reflector below the Athabasca unconformity is referred as the "Dipping Reflector" (DR) in Hajnal et al. (2007). Regional scale seismic lines S1A and S2B of the LITHOPROBE Trans-Hudson transect carried out east and south of the Athabasca Basin reveal similar shallow W- to NW-dipping bands of reflectivity that are interpreted as a series of Paleoproterozoic high-strain zones separating the Archean Sask Craton and Paleoproterozoic Reindeer Zone to the east from the Archean Mudjatik Domain to the west (Hajnal et al. 2002, 2005; Hammer et al. 2011). Hajnal et al. (2007) suggest that this 7 kilometer thick band of mid-crustal reflectivity (DR), 
with an apparent dip of $25^{\circ}$ toward the northwest, is the signature of "a fundamental tectonic event that shaped the margin of the Hearne Craton during the THO collision". We suggest that this reflector, called herein the D1 reflector, could correspond to major shear zones formed during the M1-D1 underthrusting of the Reindeer zone beneath the Hearne craton margin, which has also been affected by nappe stacking. This resulted in the formation of an orogenic wedge where crystalline Archean rocks of the Hearne Province alternate with Wollaston Paleoproterozoic supracrustal rocks (Fig 16b). The present day depth at 12 to $22 \mathrm{~km}$ of this $\mathrm{D} 1$ reflector is equivalent to a minimum pressure of $\sim 4 \mathrm{kbar}$. If we assume that the pressure recorded in the basement just beneath the unconformity at the McArthur River mining camp is similar to that estimated at the Wolly-McClean study area (ie. $\sim 5$ kbar), then the upper part of the D1 reflector, in that location, would have been at a pressure of $\sim 9$ kbar during the D1 event. This pressure is equivalent to the pressure recorded in the Wollaston Lake and Cochrane River study areas. Taking into account that the $25^{\circ}$ dip observed in the seismic line is an apparent dip, and noting that a change in apparent dip of only $5^{\circ}$ to the southwest, we speculate that the upper part of the D1 reflector could be currently exposed $\sim 150 \mathrm{~km}$ to the north-east in the Wollaston Lake area.

\section{M2-D2 event: differential exhumation in sinistral transpressive regime}

The second regional tectono-metamorphic event M2-D2 was responsible for the exhumation of M1 rocks during an isothermal decompression event, which led to the formation of cordierite-bearing M2 assemblages that recorded P-T conditions at 4.5-6 kbar and $700-850^{\circ} \mathrm{C}$ throughout the entire studied area. This metamorphic event was coeval with the development of a steeply-dipping N40 ${ }^{\circ} \mathrm{S} 2 / \mathrm{C} 2$ foliation and the $\mathrm{N} 10^{\circ} \mathrm{C}^{\prime} 2$ shear zones that significantly overprint the $\mathrm{S} 1$ foliation (Fig. 10). The onset of the M2-D2 event corresponds to the folding of S1 foliation by kilometer-scale F2 folds with eastwest trending and vertical axial planes during a north-south horizontal crustal shortening (Fig. 10). The subsequent rotation of the early F2 fold axes (Fig. 10) to a N40 ${ }^{\circ}$ direction, appearance new F2 folds, and development of penetrative steeply-dipping S2/C2/C2' structures formed progressively in the same heterogeneous sinistral transpressive tectonic regime with NE-SW-directed strike-slip shearing and north-south shortening. 

reveal, in the Wollaston Domain and the WMTZ, distinct steep and narrow non-reflective (seismically-transparent) zones that separate crustal blocks of variable size in which the early west to north-west shallow-dipping structures (S1) are preserved (Hajnal et al. 2005, 2007). These steep structures have been interpreted as crustal-scale shear zones that have been reactivated as discrete brittle faults (Hajnal et al. 2005), and could correspond to the steep S2/C2/C2' ductile high-strain zones revealed in this study.

There is no clear syn-D2 P-T gradient, nor jumps in P and/or T, across the main S2 trend that forms the WMTZ. This result contrasts with studies carried out $200 \mathrm{~km}$ to the south-west, where changes in metamorphic conditions have been inferred across the North-East trending D2 shear zones (Annesley et al. 2005). However, we do observe a change in the metamorphic evolution along the D2 strike. From northeast to southwest, the basement has been affected by a differential isothermal decompression event between $\mathrm{D} 1$ and $\mathrm{D} 2$, with $\Delta \mathrm{P}$ of $\sim 5$ to 1 kbar from $\mathrm{NE}$ towards $\mathrm{SW}$. We suggest that the differential exhumation, which juxtaposed the northern-eastern part of the studied area (Wollaston Lake and Cochrane River) and the Wolly-McClean exploration drilling project at the same structural level at an approximate depth of 12 to $15 \mathrm{~km}$, occurred in response to the post- thickening isostatic re-equilibration of the Hearne crust (Fig. 16).

\section{Tectonic significance of the M1-D1 to M2-D2 events}

The structural and metamorphic analysis carried out in the Cochrane River, the northern part of the Wollaston Lake, and the Wolly-McClean exploration project area shows a transition from a D1 N-S shortening and underthrusting to a D2 NE-SW sinistral shearing along the WMTZ. Wollaston Group sediments were buried via a series of north to north-west-dipping thrusts with top-tothe-south to south-east kinematics. This led to the thickening of the Hearne margin via the formation of an orogenic wedge. This M1-D1 event is correlated with the $\mathrm{D}_{\mathrm{P} 1}$ and $\mathrm{DP}_{2 \mathrm{a}}$ stage defined by Annesley et al. (2005) in the WMTZ (Table 1). In Table 1, the deformation phases of Harper et al. 
650 (2005) and Card et al. (2006), defined in the Wollaston Lake area and Cochrane River area,

651 respectively, are presented for comparison. This M1-D1 event is interpreted as the early collision stage

652 of the Trans-Hudson Orogen which occurred between 1.86 and $1.82 \mathrm{Ga}$ (Annesley et al. 2005) after

653 the initial stages of accretion (1.88-1.86 Ga) (Corrigan et al. 2009). In their interpretations, the

654 collision and thickening is the result of the northward drift of the Archean Superior Province and Sask

655 Craton with the juvenile Paleoproterozoic rocks of the Reindeer Zone (arc-related and derived

656 sedimentary rocks) accreted on the south-eastern margin of the Hearne Craton.

657 Evidence of crustal thickening is also reported, south-east of the WMTZ, in the Rottenstone

658 domain, that corresponds to the northwesternmost component of the juvenile Paleoproterozoic

659 Reindeer Zone (Culshaw and Clarke 2009). Similar gently northwest-dipping migmatitic S1 foliation

660 has been interpreted by Culshaw and Clarke (2009) as either remnants of a Himalayan-like type of

661 extrusion zone or a stack of ductile thrust sheets. The timing of the development of the $\mathrm{S} 1$ foliation is

662 uncertain with respect to the arrival of the Sask and Superior cratons. Culshaw and Clarke (2009)

663 propose two models. The D1 Himalayan-type extrusion or thrust staking occurred (1) at ca. $1815 \mathrm{Ma}$

664 until the arrival of the superior craton or (2) between 1835 and 1815 Ma just after the arrival of the

665 Sask Craton.

666 The M2-D2 event corresponds to the transition from a stage of continental collision with crustal

667 thickening (or Himalayan-type extrusion) to a sinistral transpressive regime. This event is comparable

668 with $\mathrm{D}_{\mathrm{P} 2 \mathrm{~b}}$ and $\mathrm{D}_{\mathrm{P} 3}$ stage documented by Annesley et al. (2005) (Table 1) dated between 1.82 and 1.775

669 Ga (Fig. 16). This event, which has been recognized at the scale of the central THO, is referred as a

670 late collisional event (e.g. Ansdell 2005; Corrigan 2009) and results from the oblique convergence of

671 the Superior Province and Sask craton with the Churchill craton (Ansdell 2005). The oblique

672 collisions induced a lateral extrusion of the northwestern part of the collision zone along the Superior

673 Province boundary in an anti-clockwise indentation, resulting in a penetrative steeply-dipping sinistral

674 transpression (Hajnal et al. 1996). This late escape tectonic setting is comparable to the east side of the

675 Himalayas (Kuiper et al. 2011). Searle and St-Onge (2004) and St-Onge and Searle (2004) argued that 
676 the tectonic record of the THO in the late Paleoproterozoic (ca. 1820-1795Ma) was similar to the

677 record of collision and indentation of India into SE Asia in the Eocene (Rowley et al. 2004)

678 The localization of the transpressive deformation along the WMTZ is also probably favored by the 679 strong viscosity contrast between the stiff orthogneisses of the Archean Mudjatik Domain and the 680 weak partially-molten Wollaston Group metasediments. However, the M2-D2 late-collisional 681 transpression is not restricted to the WMTZ. Indeed, Culshaw and Clarke (2009) have observed at 682 Davin Lake in the Rottenstone Domain, a D2 deformation that is, very similar to our observations, 683 with the development of upright horizontal folds (F2) that overprint the previous gently dipping S1 684 foliation. In high strain zones, the supracrustal S1 gneissic foliation is heterogeneously transposed into 685 a S2 foliation.

\section{Geodynamic Significance of the Wollaston Mudjatik Transition Zone}

$$
\text { The Wollaston -Mudjatik Transition Zone is defined as a major northeast-trending zone that }
$$
separates the western Mudjatik Domain, dominated by Archean basement, from the eastern Wollaston Domain that is mostly composed of Paleoproterozoic metasedimentary rocks. Compared to the Churchill Province and Superior Province blocks, the whole WMTZ has been strongly deformed and metamorphosed during the Trans-Hudson Orogen.

Annesley and Madore (1994) initially suggested that the WMTZ marks an abrupt change of structural style and speculated that it is a major crustal-scale thrust and/or strike-slip zone. In contrast, Annesley et al. (2005), Gyorfi et al. (2007) or Hajnal et al. (2007) suggested that the junction between the Wollaston and Mudjatik domains was wider, variable in width and highly heterogeneous in terms of lithology, deformation style and P-T conditions. But in all cases, the WMTZ is regarded as a fundamental tectonic boundary that reworked the Hearne margin during the THO (Hajnal et al. 2007).

Our results are consistent with previous studies that have highlighted the heterogeneous style of the deformation. We show that the WMTZ consists of a network of anastomosed high strain zones. The main D2 high-strain zone is located along the western edge of the MWTZ, between Crozier Island and Lejour Island (Figs. 5, 15). More to the west, into the Mudjatik Domain, D1 becomes predominant 
702

703

704

705

706

707

708

709

710

711

712

713

714

715

716

717

718

719

720

721

722

723

724

725

726

727

and better preserved within the Archean felsic orthogneisses. Elsewhere, in the WMTZ, the D2 deformation (particularly to the east of the D2-high strain corridor) is very heterogeneous and consists of a kilometer-scale network of anastomosing D2 shear zones that define lenses within which D1 flatlying structures are best preserved. These D2 low strain zones also correspond to domains where the Archean basement is exposed, interleaved with Wollaston group meta-sedimentary rocks. We suggest that the alternation of Archean domains with the Paleoproterozoic supracrustal rocks of the Wollaston Group, representing the typical architecture of the WMTZ, is due to some extent to the D2 heterogeneous sinistral transpression. However, the final geometry also depends on the initial geometry of the Hearne margin before the D1 convergence. Tran et al. $(2003,2008)$ suggested that the Wollaston Group sediments were deposited on the Archean Hearne Craton in a passive margin setting that evolved to a back-arc basin between ca. $2.1 \mathrm{Ga}$ (rifting) and $1.92 \mathrm{Ga}$ (formation of the Rottenstone continental arc that now belongs to the Reindeer zone). Rifting may have been responsible for the formation of horsts and grabens or half-grabens, not only along the Hearne margin but also within the Hearne craton where Wollaston group sediments were deposited (see Tran et al. 2003 for more details on the depositional and tectonic setting of the Wollaston Group) (Fig. 16a).

These Paleoproterozoic half-grabens and tilted faulting of Archean block were tectonically inverted during the D1 convergence, to form a stack of ductile thrust sheets (Fig. 16b). The transpressional deformation D2 could have emphasized the inversion and the formation of interleaved domains consisting either of Archean gneiss or Paleoproterozoic Wollaston sediments in the WMTZ (Fig. 16c).

In brief, the WMTZ corresponds to the reworked passive margin of the Hearne craton domain. The finite geometry of the WMTZ is the result of the superposition of a complex initial geometry, typical of all passive margins and back-arc basin, and the D1 and D2 Trans-Hudson deformation.

The WMTZ appeared as a crustal segment enriched in metasedimentary rocks, as presently indicated by geological mapping (Macdonald and Slimmon 1999) and the coincidence of the WMTZ with a significant aeromagnetic low that reflects a high amount of pelitic and semi-pelitic metasedimentary rock in the crust (Li et al. 2013). 


\section{Implications for the formation of uranium-enriched lithologies}

The great majority of the uranium deposits in the eastern part of the Athabasca Basin are located along the WMTZ, where the Athabasca Group strata unconformably overlie highly-deformed, partiallymelted Wollaston Group metasedimentary rocks and the associated locally-present granitic pegmatites and leucogranites. These rocks, locally containing trace to minor amounts of U-rich monazite, are considered by some authors as "uranium proto-ores", or uranium-enriched lithologies, formed during the Trans-Hudson Orogen (Fig. 1; Annesley and Madore 1999; Annesley et al. 2000; Hecht and Cuney 2000; Madore et al. 2000; Cuney 2009; Mercadier et al. 2010).

Annesley et al. (2005) proposed that post-Hudsonian brittle reactivation of structures within the WMTZ and consequent heat and fluid flow along them controlled the locations of the unconformitytype uranium deposits formed after the deposition of the Athabasca Group (i.e. after $\sim 1.7 \mathrm{Ga}$ ). This interpretation implies that the location of uranium-enriched lithologies (i.e. granites and pegmatites containing U-rich monazite and uraninite) and the later unconformity-type uranium deposits were both mostly controlled by the presence of Wollaston Group metasediments affected by the D2 north-easttrending structures. While occurrences of uranium-enriched pegmatites have been reported throughout the D2 WMTZ basement around and beneath the Athabascan Group (Mawdsley 1952, 1953, 1955; Parslow and Thomas 1982; Thomas 1983; Parslow et al. 1985; Annesley \& Madore 1999; Annesley et al. 2000; Madore et al. 2000), as well as in the basement exposed south-east of the Athabasca (Fraser Lakes area and others, McKechnie et al. 2012a, 2013), it is noteworthy that uranium-enriched pegmatites are almost unknown in the basement exposed just north-east of the Athabasca Basin along the D2 WMTZ trend where we have performed this study. This suggests that the presence of Wollaston Group metasedimentary rocks and D2 deformation of the WMTZ, are thus not the only parameters that controlled the location of uranium-enriched lithologies.

This along-strike change in uranium content or uranium fertility within the WMTZ could be related to differences in the source rock composition. However, we want to emphasize, in this contribution, the possible role of the D1 pressure gradient revealed by our thermobarometric estimations. The increase in M1-D1 pressure from 5 to $11-12 \mathrm{kbar}(1 \mathrm{kbar}=100 \mathrm{MPa})$ towards the north-east means that the 
755

756

757

758

759

760

761

762

763

764

765

766

767

768

769

770

771

772

773

774

775

776

777

778

779

780

basement exposed to the north-east of the Athabasca Basin (ie. in the Wollaston Lake and Cochrane

River study areas) and the uranium-enriched basement beneath the Athabasca Basin do not belong to the same structural level (up to 10-12 km of difference) during the M1-D1 event. In other words, the Wollaston sediments have not all been affected by the same P-T evolution during the D1 event that led to the crustal thickening. The uranium-enriched pegmatites represent crystallization of a uraniumenriched magma formed by low degree of partial melting of an already-enriched protolith, i.e. the pelitic and psammo-pelitic metasedimentary rocks. We suggest that within the thickened D1/M1 WMTZ, the elevation of uranium content via emplacement of uranium-enriched pegmatites occurred mostly in the middle crust at pressures around 5 kbar.

During the M1-D1 burial of Wollaston sediments to various depths (equivalent to 12 to $5 \mathrm{kbar}$ ) (Fig. 16b), the first batches of melt produced via low-degree fluid-present melting are the most likely enriched in uranium. Our observations suggest that part of these silicate-melts were segregated, transferred and collected in the middle crust (at ca. 5 kbar) where they have differentiated and crystallized to produce uranium-enriched pegmatites. The transfer and collection of melt in the middle crust could have been favored by the development of crustal-scale steep S2 / C2 and C2' shear zones

Our model implies that the melt, from which uranium-enriched pegmatite derived, were formed during the M1-D1 event. Furthermore, field observations, petrology, and thermodynamic modeling show that partial melting was still active during the M2-D2 deformation. Therefore, we do not exclude the possibility that uranium-enriched pegmatites could also be the product of differentiation of M2-D2 melts. The higher uranium fertility of the upper levels of the crust (at $\sim 4-5$ kbar) is reinforced by the development at a crustal scale of steep S2/C2 and C2' shear zones that favor melt segregation and transfer of melt towards upper levels where they could differentiate and crystallize as uraniumenriched pegmatites. Mercadier et al. (2013) have dated uranium oxides in pegmatites within the WMTZ at ca. 1.81 and $1.76 \mathrm{Ga}$ indicating uranium-enriched pegmatite formation during peak- and post-thermal evolution, respectively. McKechnie et al. (2012) obtained U-Pb-Th chemical ages on uraninite ranging from 1.85 to $1.80 \mathrm{Ga}$ that could also be related to peak metamorphism. Although we 
781

782

783

784

785

786

787

788

789

790

791

792

793

794

795

796

797

798

799

800

801

802

803

804

805

806

do not have precise age constraints on M1-D1 and M2-D2 events, we suggest that uranium-enriched pegmatites were formed during both tectono-metamorphic stages.

The final stage that contributed to the formation of the unconformity-type deposits corresponds to a brittle post-Hudsonian and post-Athabasca reactivation of the D2 shear zones that produced a permeable conduit system for the migration of oxidizing basinal brines and basin-derived diagenetichydrothermal basement fluids. These diagenetic-hydrothermal basement fluids may have leached uranium from the basement lithologies, including uranium-enriched pegmatites (e.g. Hecht and Cuney 2000; Mercadier et al. 2010).

\section{Conclusions}

A critical aspect of the geodynamic model developed in this contribution is the change in structural and metamorphic style that affected the Hearne Craton margin from $1.86 \mathrm{Ga}$ to $1.78 \mathrm{Ga}$ as a consequence of the collision of the Trans-Hudson Orogen. The early collision between the Hearne and Reindeer Zone, Sask Craton and Superior Province is characterized by the burial of the thinned Hearne margin via northward-underthrusting during M1-D1 at ca. 1.82 Ga to a north-east sinistral transpressional tectonic regime during M2-D2 at ca. $1.78 \mathrm{Ga}$ (Fig. 15, 16).

The present-day geometry of the Wollaston-Mudjatik Transition Zone, consisting of Archean domains alternating with the Paleoproterozoic supracrustal rocks of the Wollaston Group, is therefore the result of the initial geometry of the thinned passive margin, with Paleoproterozoic half-grabens and tilted fault Archean blocks (horsts), that were tectonically inverted and buried during Trans-Hudsonian D1 shortening and strongly deformed during D2 transpression (Fig. 16). The D2 deformation, characterized by steeply-dipping and vertical crustal scale shear zones, is localized in a narrow domain (the future WMTZ) where the viscosity contrast between the rheologically-strong Archean Mudjatik Domain and the partially-melted and weaker Paleoproterozoic Wollaston rocks was most strongly developed. Following previous authors, we acknowledge that both the Wollaston Group metasedimentary rocks and D2 deformation of the WMTZ were important parameters that controlled the location of uranium-enriched pegmatites and granites (Fig. 1), but in addition we argue that the 
807 maximum depth of burial of the Wollaston Group sediments during D1 constitutes also another key

808 parameter that should be taken into account for the formation of the uranium-enriched pegmatites.

809 Indeed, in this respect, we suggest that during the D1/M1 event, prograde partial melting of Wollaston

810 metasediments will produce uranium enriched melt irrespective of the maximum burial depth.

811 However, our field observations show that uranium-enriched pegmatites are restricted to the middle

812 crust, at pressures around $5 \mathrm{kbar}(1 \mathrm{kbar}=100 \mathrm{MPa})$. We suggest that the first batches of melt, that are

813 likely the most enriched in uranium, could have been transferred upwards to the mid-crust owing to

814 the development of crustal scale D2 shear zones. During the final stage of the THO, the brittle

815 reactivation of the D2 shear zones produced a permeable conduit system suitable for the migration of

816 oxidizing basinal brines and basin-derived diagenetic-hydrothermal basement fluids that may have

817 contributed to the formation of the unconformity-type deposits.

818 From the above, we speculate that peak-pressure reached during M1-D1 event, in addition to the

819 presence of partially-melted Wollaston group and the development of D2 transpressive shear zones

820 could be used as a prospection guide for Trans-Hudson uranium-enriched lithologies. Regarding D1

821 pressure, greater uranium enrichment most likely occurred in the middle crust at a pressure of $\sim 4-5$

822 kbar, rather than in the lower crust.

\section{Acknowledgements}

824 This research was funded and financially supported by AREVA. This research was also partly

825 supported by the French RENATECH network, which provided access to the electron microscope of

826 the MIMENTO platform of the University of Franche-Comté. The project would not have possible

827 without the access to the drill core from the Wolly-McClean exploration project provided by AREVA

828 Resources Canada. Particular mention should be made of the significant contributions of Jean-Louis

829 Feybesse, Jean-Pierre Milési, and Jean-Luc Lescuyer who gave birth to this project and participated in

830 the sampling of drill-core. Sincere thanks to the Hatchet Lake Lodge for their assistance in the field

831 and for reliable float plane service. Didier Convert-Gaubier is thanked for preparing the thin sections 
832 and Maxime Mermet for his assistance in sawing, milling and sieving of samples. The authors thank 833 the two anonymous reviewers for their constructive reviews. 


\section{References}

835 Alexandre, P., Kyser, K., Thomas, D., Polito, P., and Marlatt, J. 2009. Geochronology of

836 unconformity-related uranium deposits in the Athabasca Basin, Saskatchewan, Canada and their

837 integration in the evolution of the basin. Mineralium Deposita, 44: 41-59.

838 Annesley, I.R., and Madore, C. 1991. The Wollaston Group and its underlying Archean basement:

839 Final Report. Saskatchewan Research Council. Publication R-1230-4-C-91, 140 p.

840 Annesley, I.R., and Madore, C. 1994. A geological study of the Wollaston-Mudjatik domain boundary

841 in the Wollaston Lake area, Hearne Province, Saskatchewan. Saskatchewan Research Council,

842 Publication R-1230-6-C-94, 162 p.

843 Annesley, I.R., and Madore, C. 1999. Leucogranites and pegmatites of the sub-Athabasca basement,

844 Saskatchewan: U protore? In Mineral deposits: processes to processing. Edited by C.J. Stanley et al.

845 Balkema, Rotterdam, The Netherlands, Volume 1, pp. 297- 300.

846 Annesley, I.R., and Madore, C. 2002. Thermotectonics of Archean/ Paleoproterozoic basement to the

847 eastern Athabasca unconformity type uranium deposits. In Uranium deposits: from their genesis to

848 their environmental aspects. Edited by B. Kribek and J. Zeman. Czech Geological Survey, Prague,

849 Czech Republic, pp. 33-36.

850 Annesley, I.R., Madore, C., and Shi, R. 1997a. Thermotectonic evolution of the Wollaston EAGLE

851 Project Area. In thermotectonic and uranium metallogenic evolution of the Wollaston EAGLE Project

852 area. Edited by I.R. Annesley, C. Madore, R. Shi and D.H. Quirt. Saskatchewan Research Council

853 Publication No. R-1420-2-C-97, pp. 1-62.

854 Annesley, I.R., Madore, and C., Krogh, T.E. 1997b. U-Pb geochronology of thermotectonic events in

855 the Wollaston Domain Lake area, Wollaston Domain: a summary of 1994-1996 results. In Summary

856 of Investigations 1997, Saskatchewan Geological Survey, Saskatchewan Energy and Mines,

857 Miscellaneous Report. 97-4, pp. 162-176. 
858

859

860

861

862

863

864

865

866

867

868

869

870

871

872

873

874

875

876

877

878

879

880

881

882

Annesley, I.R., Madore, C., and Krogh, T.E. 1997c. U-Pb geochronology of peraluminous pegmatites from the Wollaston Lake area, northern Saskatchewan. Geological Association of Canada Mineralogical Association of Canada, Program with Abstracts, 22: A-4.

Annesley, I.R., Madore, C., Krogh, T.E., Kwok, Y.Y., and Kamo, S.L. 1999. New U-Pb zircon and monazite geochronological results for Archean and Paleoproterozoic basement to the southeastern part of the Athabasca Basin, Saskatchewan. In Summary of Investigations 1999, Volume 2, Saskatchewan

Geological Survey, Saskatchewan Energy and Mines, Miscellaneous Report. 99-4.2, pp. 90-99.

Annesley, I.R., Madore, C., Kusmirski, R.T., and Bonli, T. 2000. Uraninite bearing granitic pegmatite, Moore Lakes, Saskatchewan: Petrology and UTh- Pb chemical ages. In Summary of Investigations 2000, Saskatchewan Geological Survey, Saskatchewan Energy and Mines, Miscellaneous Report. 2000-4.2, pp. 201-211.

Annesley, I.R., Madore, C., and Portella, P. 2001. Paleoproterozoic structural, metamorphic, and magmatic evolution of the eastern sub-Athabasca basement: Controls on unconformity-type uranium deposits. In A hydrothermal odyssey extended conference abstracts 2001, Townsville, Australia, May 17-19, 2001. Edited by P.J. Williams. James Cook University Economic Geology Research Unit Contribution 59, pp. 3-4.

Annesley, I.R., Madore, C., and Portella, P. 2005. Geology and thermotectonic evolution of the western margin of the Trans-Hudson Orogen: evidence from the eastern sub-Athabasca basement, Saskatchewan. Canadian Journal of Earth Sciences, 42: 573-597.

Ansdell, K.M. 2005. Tectonic Evolution of the Manitoba-Saskatchewan Segment of the Paleoproterozoic Trans-Hudson Orogen, Canada. Canadian Journal of Earth Sciences, 42: 741-59. Berman, R.G., Sanborn-Barrie M., Stern R.A., and Carson C. J. 2005. Tectonometamorphism at Ca.2.35 and 1.85 Ga in the Rae Domain, Western Churchill Province, Nunavut, Canada: insights from structural, metamorphic and in situ geochronological analysis of the southwestern Committee Bay Belt. The Canadian Mineralogist, 43: 409-42. 
883

884

885

886

887

888

889

890

891

892

893

894

895

896

897

898

899

900

901

902

903

904

905

906

907

Bickford, M., Mock, T., Steinhart III, W., Collerson, K., and Lewry, J. 2005. Origin of the Archean

Sask Craton and its extent within the Trans-Hudson Orogen: evidence from $\mathrm{Pb}$ and $\mathrm{Nd}$ isotopic compositions of basement rocks and post-orogenic intrusions. Canadian Journal of Earth Sciences, $\mathbf{4 2}$ : 659-684.

Card, C.D., Harper, C.T., Barsi, N., Lesperance, J., and Smith, J.S. 2006a. Investigation of the Wollaston-Mudjatik Transition, Charcoal Lake and Cochrane River (Parts of NTS 64L-9,-10, -11,-14,15 and -16). In Summary of Investigations 2006, Volume 2, Saskatchewan Geological Survey, Saskatchewan Industry and Resources, Miscellaneous Report. 2006-4.2.

Card, C.D., Harper, C.T., Barsi, N., Lesperance, J., and Smith, J.S. 2006b. Bedrock Geology of the Cochrane River area, Northeast Wollaston Domain (Parts of NTS 64L/10, /11, /14, /15); 1/ 50000 scale preliminary map. In Summary of Investigations 2006, Volume 2, Saskatchewan Geological Survey, Saskatchewan Industry and Resources, Miscellaneous. Report. 2006-4.2.

Card, C.D., Harper, C.T., Barsi, N., Lesperance J., and Smith, J.S. 2006c. Bedrock Geology of the Charcoal Lake area, Northeast Wollaston Domain (parts of NTS area 64L/ 9, /10, /15 and /16); 1:50 000 scale preliminary map. In Summary of Investigations 2006, Volume 2, Saskatchewan Geological Survey, Saskatchewan Industry and Resources, Miscellaneous Report. 2006-4.2.

Chiarenzelli, J., Aspler, L., Villeneuve, M., and Lewry, J. 1998. Early Proterozoic evolution of the Saskatchewan craton and its allochthonous cover, Trans-Hudson orogen. Journal of Geology, 106 : $247-267$.

Choukroune, P. 1995. Déformation et déplacements dans la croûte terrestre, Éditions Masson.

Chu, X., and Ague, J.J. 2013. Phase equilibria for graphitic metapelite including solution of CO2 in melt and cordierite: implications for dehydration, partial melting and graphite precipitation. Journal of Metamorphic Geology, 31: 843-862. doi:10.1111/jmg.12047

Corrigan, D. 2012. Paleoproterozoic crustal evolution and tectonics processes: Insights from the LITHOPROBE program in the Trans-Hudson orogen, Canada. Chapter 4 In Tectonic Styles in 
908 Canada: The LITHOPROBE Perspective. Edited by J.A. Percival, F.A. Cook, and R.M. Clowes.

909 Geological Association of Canada, Special Paper 49, pp. 237-284.

910 Corrigan, D., Machattie, T. G., and Chakungal, J. 1999. The Wathaman Batholith and its relation to

911 the Peter Lake Domain: insights from recent mapping along the Reindeer Lake transect, Trans-Hudson

912 Orogen. In Summary of Investigations 1999, Volume 2, Saskatchewan Geological Survey,

913 Miscellaneous Report. 99-4.2, pp.132-142.

914 Corrigan, D., Hajnal, Z., Németh, B., and Lucas, S.B. 2005. Tectonic framework of a Paleoproterozoic

915 arc-continent to continent-continent collisional zone, Trans-Hudson Orogen, from geological and

916 seismic reflection studies. Canadian Journal Earth Sciences, 42: 421-434.

917 Corrigan, D., Pehrsson, S., Wodicka, N., Kemp, E. de. 2009. The Paleoproterozoic Trans-Hudson

918 Orogen: a prototype of modern accretionary processes. Geological Society, London, Special

919 Publications, 327: 457-479.

920 Cuney, M. 2009. The extreme diversity of uranium deposits. Mineralium Deposita, 44: 3-9. doi:

$921 \quad 10.1007 / \mathrm{s} 00126-008-0223-1$

922 Cumming, G.L., Krstic, D. 1992. The age of unconformity-related uranium mineralization in the

923 Athabasca Basin, northern Saskatchewan. Canadian Journal of Earth Sciences, 29: 1623-1639.

924 Culshaw, N.G., and Clarke, D.B. 2009. Structural History and Granite Emplacement in the

925 Rottenstone Domain during Closure of the Trans-Hudson Orogen, Davin Lake, Northern

926 Saskatchewan. Canadian Journal of Earth Sciences, 46: 287-306.

927 Fayek, M., and Kyser, T.K. 1997. Characterization of multiple fluid-flow events and rare-earth-

928 element mobility associated with formation of unconformity-type uranium deposits in the Athabasca

929 Basin, Saskatchewan. Canadian Mineralogist, 35: 627-658.

930 Fayek, M., Harrison, T.M., Ewing, R.C., Grove, M., and Coath, C.D. 2002a. O and Pb isotopic

931 analyses of uranium minerals by ion microprobe and $\mathrm{U}-\mathrm{Pb}$ ages from the Cigar Lake deposit:

932 Chemical Geology, 185: 205-225. 
933 Fayek, M., Kyser, T.K., and Riciputi, L.R. 2002b. U and Pb isotope analysis of uranium minerals by

934 ion microprobe and the geochronology of McArthur River and Sue zone uranium deposits,

935 Saskatchewan, Canada. Canadian Mineralogist, 40: 1553-1569.

936 Fumerton, S. L., Stauffer, M. R. and Lewry, J. F. 1984. The Wathaman Batholith: largest known

937 Precambrian pluton. Canadian Journal of Earth Sciences, 21: 1082-1097.

938 Gaidies, F., Pattison, D.R.M., and Capitani, C. 2011. Toward a quantitative model of metamorphic

939 nucleation and growth. Contributions to Mineralogy and Petrology, 162: 975-993.

940 doi:10.1007/s00410-011-0635-2

941 Gyorfi, I., Hajnal, Z., White, D.J., Takacs, E., Reilkoff, B., Annesley, I.R, Powell, B., and Koch, R.

942 2007. High resolution seismic survey from the McArthur River region: contributions to mapping of

943 the complex P2 uranium ore zone, Athabasca Basin, Saskatchewan. In EXTECH IV Geology and

944 Uranium EXploration TECHnology of the Proterozoic Athabasca Basin, Saskatchewan and Alberta.

945 Edited by C.W. Jefferson and G.Delaney. Geological Survey of Canada, Bulletin 588, pp. $397-412$.

946 Hammer P.T.C., Clowes, R.M., Cook, F.A., Vasudevan, K., and Van der Velden, A.J. 2011. The big

947 picture: A lithospheric cross section of the North American continent. Geological Society of America,

948 21: 4-10. doi:10.1130/GSATG95A.1

949 Hajnal, Z., Lucas, S., White, D., Lewry, J., Bezdan, S., Stauffer, M.R. and Thomas, M.D. 1996.

950 Seismic Reflection Images of High-Angle Faults and Linked Detachments in the Trans-Hudson

951 Orogen. Tectonics, 15: 427-39.

952 Hajnal, Z., White, D.J., Ashton, K., Clowes, R., Stauffer, M., and Maxeiner, R. 2002. 3-D perspectives

953 of the western portion of the Trans-Hudson Orogen in Saskatchewan. Geological Association of

954 Canada - Mineralogical Association of Canada Joint Annual Meeting, Saskatoon, Saskatchewan. p.

95544.

956 Hajnal, Z., Lewry, J., White, D., Ashton, K., Clowes, R., Stauffer, M., Gyorfi, I., and Takacs, E. 2005.

957 The Sask Craton and Hearne Province margin: seismic reflection studies in the western Trans-Hudson

958 Orogen. Canadian Journal of Earth Sciences, 42: 403-419. doi: 10.1139/E05-026 
959

960

961

962

963

964

965

966

967

968

969

970

971

972

973

974

975

976

977

978

979

980

981

982

983

984

Hajnal, Z., Takács, E., White, D.J., Gyorfi, I., Powell, B., and Koch, R. 2007. Regional seismic signature of the basement and crust beneath the McArthur River mine district, Athabasca Basin, Saskatchewan. In EXTECH IV: Geology and Uranium EXploration TECHnology of the Proterozoic Athabasca Basin, Saskatchewan and Alberta. Edited by C.W. Jefferson and G.Delaney. Geological Survey of Canada, Bulletin 588, (also Geological Association of Canada, Mineral Deposits Division, Special Publication 4; Saskatchewan Geological Society, Special Publication 18), pp. 389-396.

Hajnal, Z., White, D.J., Takacs, E., Gyorfi, I., Annesley I.R., Wood, G., Dowd, C.O’’ and Nimeck, G. 2010. Application of Modern 2-D and 3-D Seismic-Reflection Techniques for Uranium Exploration in the Athabasca Basin. Canadian Journal of Earth Sciences, 47: 761-82.

Harper, C.T., and Van Breemen, O. 2004. Progress report on U-Pb SHRIMP zircon geochronology and Sm-Nd isotope geochemistry of the Phelps Lake area, northeast Saskatchewan. In Summary of Investigations 2004, Volume 2, Saskatchewan Geological Survey, Saskatchewan Industry Resources, Miscellaneous Report 2004-4.2, CD-ROM, Paper A-6, 8p.

Harper, C.T., Ebel, C., Yeo, G., Card, C., and Nelson, C. 2005a. Wollaston Lake Project: Geology of the Wollaston Supergroup in the Rabbabou Bay-Wellbelove Bay area, northeast Wollaston Lake, Saskatchewan (parts of NTS 64L-6, -7, -10, and -11). In Summary of Investigations 2005, Volume 2, Saskatchewan Geological Survey, Saskatchewan Industry Resources, Miscellaneous Report. 2005-4.2, CD-ROM, Paper A-6, 25 p.

Harper, C.T., Ebel, C., Yeo, G., Card, C., and Nelson, C. 2005b. Bedrock geology of the northeastern Wollaston Lake area; Shaganappie Island sheet, (parts of NTS 64L/6 and /7): 1:50 000 scale preliminary Map. In Summary of Investigations 2005, Volume 2, Saskatchewan Geological Survey, Saskatchewan Industry Resources, Miscellaneous Report. 2005-4.2.

Harper, C.T., Ebel, C., Yeo, G., Card, C., and Nelson, C. 2005c. Bedrock geology of the northeastern Wollaston Lake area; Usam Island sheet (parts of NTS 64L/10 and /11): 1:50 000 scale preliminary Map. In Summary of Investigations 2005, Volume 2, Saskatchewan Geological Survey, Saskatchewan Industry Resources, Miscellaneous Report. 2005-4.2. 
985 Harper, C.T., Rayner, N., and Card, C. 2006. Preliminary U-Pb ages for Archean basement and

986 Proterozoic intrusion from the northern Wollaston Lake area, Saskatchewan. In Summary of

987 Investigations 2006, Volume 2, Saskatchewan Geological Survey, Saskatchewan Industry Resources,

988 Miscellaneous Report; 2006-4.2, CD-ROM, Paper A-7, 9p.

989 Harper, C.T., Card, C., Davis, W., and Creaser, R. 2007a. Update on the quartzite-Amphibolite

990 Succession at Wollaston Lake: New Mapping, U-Pb detrital zircon study, and Sm/Nd isotopic study.

991 In Summary of Investigations Volume 2, 2007, Saskatchewan Geological Survey, Saskatchewan

992 Industry Resources, Miscellaneous Report. 2007-4.2, CD-ROM.

993 Harper, C.T., Ebel, C., Yeo, G., Card, C., and Nelson, C. 2007b. Bedrock geology of the northeastern

994 Wollaston Lake area; Shaganappie Island sheet ( $2^{\text {nd }}$ Edition) (parts of NTS 64L/10 and /11): 1:50 000

995 scale preliminary map. In Summary of Investigations 2007, Volume 2, Saskatchewan Geological

996 Survey, Saskatchewan Industry Resources, Miscellaneous Report. 2007-4.2.

997 Harper, C.T., Ebel, C., Yeo, G., Card, C., and Nelson, C. 2007c. Bedrock geology of the northeastern

998 Wollaston Lake area; Usam Island sheet ( $2^{\text {nd }}$ Edition) (parts of NTS 64L/10 and /11): 1:50 000 scale

999 preliminary map. In Summary of Investigations 2007, Volume 2, Saskatchewan Geological Survey,

1000 Saskatchewan Industry Resources, Miscellaneous Report. 2007-4.2.

1001 Hecht, L., and Cuney, M. 2000. Hydrothermal alteration of monazite in the Precambrian crystalline

1002 basement of the Athabasca Basin (Saskatchewan, Canada): implications for the formation of

1003 unconformity-related uranium deposits. Mineral. Deposita, 35: 791-795. doi:10.1007/s001260050280

1004 Hoeve, J., and Quirt, D. 1984. Mineralization and host rock alteration in relation to clay mineral

1005 diagenesis and evaluation of the Middle-Proterozoic Athabasca basin, northern Saskatchewan.

1006 Saskatchewan Research Council Technical Report no. 187, 187 p.

1007 Hoeve, J., and Quirt, D. 1987. A stationary redox front as a critical factor in the formation of high 1008 grade, unconformity-type uranium ores in the Athabasca Basin, Saskatchewan, Canada. Bulletin of 1009 Mineralogy, 110: 151-171. 
1010

1011

1012

1013

1014

1015

1016

1017

1018

1019

1020

1021

1022

1023

1024

1025

1026

1027

1028

1029

1030

1031

1032

1033

Hoeve, J., and Sibbald, T. 1978. On the genesis of Rabbit Lake and other unconformity-type uranium deposits in northern Saskatchewan, Canada. Economic Geology, 73: 1450-1473.

Hoeve, J., Sibbald, T.I.I., Ramaekers, P., and Lewry, J.F. 1980. Athabasca Basin unconformity-type uranium deposits: A special class of sandstone- type deposits. In Uranium in the Pine Creek Geosyncline: Vienna. Edited by J. Ferguson and A.B. Goleby. International Atomic Energy Agency. pp. 57- 594.

Hoffman, P.E. 1988. United plates of America, the birth of a Craton: early Proterozoic assembly and growth of Laurentia. Annual Review of Earth and Planetary Sciences, 16: 543-603.

Hoffman, P.E. 1990. Subdivision of the Churchill Province and extent of the Trans- Hudson Orogen. In The Early Proterozoic Trans- Hudson Orogen of North America. Edited by J.F. Lewry and M.R. Stauffer. Geology Association of Canada Special Paper 37, pp. 15-40.

Holland, T.J.B., and Powell, R. 1998. An internally consistent thermodynamic data set for phases of petrological interest. Journal of Metamorphic Geology, 16: 309-343.

Holland, T., and Powell, R. 2003. Activity-composition relations for phases in petrological calculations: an asymmetric multicomponent formulation. Contribution Mineral Petrol, 145: 492-501.

Jefferson, C.W., and Delaney, G. 2007. EXTECH IV: Geology and Uranium Exploration TECHnology of the Proterozoic Athabasca Basin, Saskatchewan and Alberta. Geological Survey of Canada, Bulletin 588 (also Geological Association of Canada, Mineral Deposits Division, Special Publication 4; Saskatchewan Geological Society, Special Publication 18), 643 p. Jefferson, C.W., Thomas, D.J., Gandhi, S.S., Ramaekers, P., Delaney, G., Brisbin, D., Cutts, C., Portella, P., and Olson, R.A. 2007a. Unconformity-associated uranium deposits of the Athabasca Basin, Saskatchewan and Alberta. In EXTECH IV: Geology and Uranium EXploration TECHnology of the Proterozoic Athabasca Basin. Edited by C.W. Jefferson and G.Delaney. Geological Survey of Canada, Bulletin 588, pp. 23-68. 
1034 Jefferson, C.W., Thomas, D., Quirt, D., Mwenifumbo, C.J., and Brisbin, D. 2007b. Empirical models 1035 for Canadian unconformity-associated uranium deposits. In: Proceedings of Exploration 07: Fifth 1036 Decennial International Conference on Mineral Exploration (Milkereit, B., ed.), pp. 741-769.

1037 Kuiper, Y.D., Lin, S., and Böhm, C.O. 2011. Himalayan-type escape tectonics along the Superior 1038 Boundary Zone in Manitoba, Canada. Precambrian Research, 187: 248-262.

1039 Kyser, T.K., and Cuney, M. 2008. Unconformity-related uranium deposits: Mineralogical Association 1040 of Canada Short Course, 39: 7-95.

1041 Kyser, T.K., and Stauffer, M. 1995. Petrogenesis and ages of plutons in the Central Metavolcanic Belt, 1042 La Ronge Domain. In Trans-Hudson Orogen Transect. Edited by Z. Hajnal and J. Lewry. Lithoprobe 1043 Report, volume 48, pp. 122-130.

1044 LeCheminant, A.N., and Heaman, L.M. 1989. Mackenzie igneous events, Canada: Middle Proterozoic 1045 hotspot magmatism associated with ocean opening. Earth and Planetary Science Letters, 96: 38-48.

1046 Lewry, J.F, and Collerson, K.D. 1990. Trans-Hudson Orogen: extent, subdivision, and problems. In 1047 The Early Proterozoic Trans- Hudson Orogen of North America. Edited by J.F Lewry and M.R. Stauffer. Geological Association of Canada Special Publication Paper 37, pp 1-14.

1049 Lewry, J.F., and Sibbald, T.I.I. 1977. Variation in lithology and tectonometamorphic relationships in 1050 the Precambrian basement of northern Saskatchewan. Canadian Journal of Earth Sciences 14: 1453$1051 \quad 1467$.

1052 Lewry, J.F., and Sibbald, T.I.I. 1980. Thermotectonic evolution of the Churchill province in northern 1053 Saskatchewan. Tectonophysics, 68: 45-82.

1054 Lewry, J., Hajnal, Z., Green, A., Lucas, S., White, D., Stauffer, M., Aston, K., Weber, W., and 1055 Clowes, R. 1994. Structure of Paleoproterozoic continent-continent collision zone: LITHOPROBE 1056 seismic reflection profiles across the Trans-Hudson orogen. Tectonophysics, 232: 143-160. 
1057

1058

1059

1060

1061

1062

1063

1064

1065

1066

1067

1068

1069

1070

1071

1072

1073

1074

1075

1076

1077

1078

1079

1080

Li, Z., Bethune, K.M., Chi, G., Bosman, S.A., and Card, C.D. 2013. Preliminary 3D Modelling and Structural. In interpretation of Southeastern Athabasca Basin. Geological Survey of Canada, Open File 7426, 21 p. doi: $10.4095 / 292715$

Macdonald, R. and Slimmon, W.L. (compilers). 1999. Geological map of Saskatchewan;

Saskatchewan Industry and Resources, 1:1 000000 scale.

Madore, C., and Annesley, I.R. 1993. Metamorphic pressure temperature conditions of the basal Aphebian Wollaston Group, Hearne Province, Saskatchewan. Geological Association of Canada Mineralogical Association of Canada, Program with Abstracts, 18: A-65.

Madore, C., and Annesley, I.R. 1997a. Petrology of biotite-garnet- cordierite pelitic gneisses in the Wollaston Lake area, Hearne Province, Saskatchewan. Geological Association of Canada Mineralogical Association of Canada, Program with Abstracts, 22: A-96.

Madore, C., and Annesley, I.R. 1997b. Graphitic pelitic gneisses of the Paleoproterozoic Wollaston Group, Hearne Province, Saskatchewan. In Mineral deposits: research and exploration — where do they meet? Edited by H. Papunen. Balkema, Rotterdam, the Netherlands, pp. 79-82.

Madore, C., Annesley, I.R., Kwok, K.K., and Krogh, T.E. 1999a. Petrography, geochemistry, and age of granitic pegmatites from the Close Lake and Epp Lake areas, Mudjatik Domain, Saskatchewan. Geological Association of Canada - Mineralogical Association of Canada, Program with Abstracts, 23: A-77.

Madore, C., Annesley, I.R., and Tran, H.T. 1999b. Petrology and geochemistry of Paleoproterozoic Wollaston Group metasediments from the eastern Keller Lake-Siemens Lake area, Saskatchewan: A preliminary interpretation. In Summary of investigations 1999, Vol. 2. Saskatchewan Geological Survey, Saskatchewan Energy and Mines, Miscellaneous Report 99-4.2, pp. 80-89.

Madore, C., Annesley, I.R., and Wheatley, K. 2000. Petrogenesis, age, and uranium fertility of peraluminous leucogranites and pegmatites of the Mc- Clean Lake / Sue and Key Lake / P-Patch 
1081 deposit areas, Saskatchewan. In Proceedings of The Millennium Geoscience Summit, University of 1082 Calgary, GeoCanada, Canada, p. 1041.

1083 Mawdsley, J.B. 1952. Uraninite-bearing deposits, Charlebois Lake area, northeastern Saskatchewan. 1084 Canadian Institute of Mining Metallurgy and Petroleum, 482: 366-375.

1085 Mawdsley, J.B. 1953. Uraninite-bearing fine-grained pegmatite of the Charlebois Lake area 1086 northeastern Saskatchewan. Geology Society of America, 64: 1550.

1087

1088

Mawdsley, J.B. 1955. Radioactive pegmatites of northern Saskatchewan. Canadian Mining Journal, 76: $53-56$.

1089

McKechnie, C.L., Annesley, I.R., and Ansdell, K.M. 2012a. Radioactive abyssal granitic pegmatites and leucogranites in the Wollaston Domain, northern Saskatchewan, Canada: Mineral compositions

1091 and conditions of emplacement in the Fraser Lakes area. Canadian Mineralogist, 50: 1637-1667.

1092

McKechnie, C.L., Annesley, I.R., and Ansdell, K.M. 2012b. Medium- to low-pressure politic gneisses

1093

of Fraser Lakes zone B, Wollaston Domain, northern Saskatchewan, Canada: Mineral compositions,

1094 metamorphic P-T-t path, and implications for the genesis of radioactive abyssal granitic pegmatites.

1095 Canadian Mineralogist, 50: 1669-1694.

1096

McKechnie, C.L., Annesley, I.R., and Ansdell, K.M. 2013. Geological setting, petrology, and

1097 geochemistry of granitic pegmatites and leucogranites hosting U-Th-REE mineralization at Fraser

1098

1099

Lakes zone B, Wollaston Domain, northern Saskatchewan, Canada. Exploration and Mining Geology, 21: $1-26$.

Mercadier, J., Richard, A., Boiron, M.-C., Cathelineau, M., and Cuney, M. 2010. Migration of brines in the basement rocks of the Athabasca Basin through microfracture networks (P-Patch U deposit, Canada). Lithos, 115:121-136. 
1105 (Saskatchewan, Canada): A Uranium Source for Unconformity-Related Uranium Deposits? Economic 1106 Geology 108: 1037-1065. doi:10.2113/econgeo.108.5.1037

1107 Meyer, M.T., Bickford, M.E., and Lewry, J.F., 1992. The Wathaman Batholith: an Early Proterozoic 1108 continental arc in the Trans-Hudson Orogenic Belt, Canada. Geological society of America Bulletin, 1109 104: 1073-1085.

Orrell, S.E., Bickford, M.E., and Lewry, J.F. 1999. Crustal evolution and age of thermotectonic 1111 reworking in the western hinterland of the Trans-Hudson Orogen, northern Saskatchewan.

1112 Precambrian Research, 95: 187-223.

1113 Parslow, G.R., Brandstätter, F., Kurat, G. and Thomas, D.J. 1985. Chemical ages and mobility of U 1114 and Th in anatectites of the Cree Lake Zone, Saskatchewan. Canadian Mineral, 23: 543-551.

1115 Parslow, G.R., Thomas, D.J. 1982. Uranium occurrences in the Cree Lake Zone. Mineralogical 1116 Magazine, 46: 163-171.

1117 Pattison, D.R.M., and Bégin, N.J. 1994. Zoning patterns in orthopyroxene and garnet in granulites: 1118 implications for geothermometry. Journal of Metamorphic Geology, 12: 387-410. doi:10.1111/j.15251119 1314.1994.tb00031.x

1120 Pattison, D.R.M., Moynihan, D.P., and McFarlane, C.R.M. 2010. Field guide to metamorphism and 1121 tectonics in the southern Purcell anticlinorium and Kootenay Arc, southeastern British Columbia 1122 (Calgary-Radium-Kimberley-Creston-Riondel-Nelson). Geological Association of Canada field 1123 guide series, $151 \mathrm{p}$.

1124 Powell, R., and Holland, T.J.B. 2008. On thermobarometry. Journal of Metamorphic Geology 26: 155-179. doi: 10.1111/j.1525-1314.2007.00756.x

Quirt, D.H. 1993. Petrology and geochemistry of the Helikian Athabasca diabase dykes,

1127 Saskatchewan. In Summary of Investigations 1993, Saskatchewan geological Survey, Saskatchewan

1128 Energy and Mines, Miscellaneous Report 93-4, pp. 174-182. 
1129 Quirt, D.H. 2003. Athabasca unconformity-type uranium deposits: one deposit type with many

1130 variations. In Proceedings of International Conference on uranium Geochemistry, Nancy, France, pp.

$1131 \quad 309-312$.

1132 Rainbird, R.H., and Davis, W.J. 2007. U-Pb detrital zircon geochronology and provenance of the late

1133 Paleoproterozoic Dubawnt Supergroup: linking sedimentation with tectonic reworking of the western

1134 Churchill Province, Canada. Geological Society of America Bulletin, 119: 314-328

1135 Rainbird, R.H., Stern, R.A., Rayner, N., and Jefferson, C.W. 2005. Age, provenance, and regional

1136 correlation of the Athabasca Group, Saskatchewan and Alberta, constrained by igneous and detrital

1137 zircon geochronology. In EXTECH IV Geology and Uranium EXploration TECHnology of the

1138 Proterozoic Athabasca Basin, Saskatchewan and Alberta. Edited by C.W. Jefferson and G.Delaney.

1139 Geological Survey of Canada, Bulletin 588 (also Saskatchewan Geological Society, Special

1140 Publication 17; Geological Association of Canada, Mineral Deposits Division, Special Publication 4),

1141 p. 193.

1142 Ramaekers, P., Jefferson, C.W., Yeo, G., Collier, B., Long, D.G.F., Catueanu, O., Bernier, S., Kupsch,

1143 B., Post, R., Drever, G., McHardy, S., Jiricka, D., Cutts, C., and Wheatley, K. 2007. Revised

1144 geological map and stratigraphy of the Athabasca Group, Saskatchewan and Alberta. Geological

1145 Survey of Canada Bulletin 588: 155-191.

1146 Ray, G.E. 1978. Reconnaissance geology: Wollaston Lake (west) area (part of NTS area 64L). In

1147 Summary of investigations 1978. Saskatchewan Geological Survey, Saskatchewan Department of

1148 Mineral Resources, Miscellaneous Report 78-10, pp. 25-34.

1149 Ray, G.E. 1979. Reconnaissance bedrock geology, Wollaston Lake east (part of NTS area 64L). In

1150 Summary of investigations 1979. Saskatchewan Geological Survey, Saskatchewan Department of

1151 Mineral Resources, Miscellaneous Report 79-10, pp. 19-28.

1152 Rayner, N., Stern, R., and Bickford, M., 2005. Tectonic implications of new SHRIMP and TIMS U-

1153 Pb geochronology of rocks from the Sask craton, Peter Lake Domain, and Hearne margin, Trans-

1154 Hudson orogen, Saskatchewan. Canadian Journal of Earth Sciences, 42: 635-657. 
1155

1156

1157

1158

1159

1160

1161

1162

1163

1164

1165

1166

1167

1168

1169

1170

1171

1172

1173

1174

1175

1176

1177

1178

1179

Rowley, D.B., Currie, B.S., Kidd, W. S. F., and Zhu, B. 2004. India-Asia collision and Himalaya-

Tibet orogenesis sensu stricto. Geology Society of America, Abstract Programs, 36: 408.

Schneider, D.A, Heizler, M. T., Bickford, M. E., Wortman, G. L., Condie, K. C. and Perilli, S. 2007.

Timing constraints of orogeny to cratonization: thermochronology of the Paleoproterozoic Trans-

Hudson orogen, Manitoba and Saskatchewan, Canada. Precambrian Research, 153: 65-95.

Searle, M.P., and St-Onge, M.R. 2004. The Trans-Hudson Orogen of North America and the

Himalaya- Karakoram-Tibetan Orogen of Asia, part 2: Structural and thermal evolution of the upper plate. Geology Society of America, Abstract Programs, 36: 408.

St-Onge, M.R., and Searle, M.P. 2004. The Trans- Hudson Orogen of North America and the Himalayan Orogen of Asia, part 1: Structural and thermal evolution of the lower plate. Geology Society of America, Abstract Programs, 36: 408.

Sibbald, T.I.I., Munday, R.J.C., and Lewry, J.F. 1977. The geological setting of uranium mineralization in northern Saskatchewan. In Uranium in Saskatchewan. Edited by C.E. Dunn. Saskatchewan Geological Society, Special Publication 3, pp.51-98.

Stauffer, M. R. 1984. Manikewan and early Proterozoic ocean in central Canada, its igneous history and orogenic closure. Precambrian Research, 25: 257-281.

Thomas, M.W. 1983. Compilation Bedrock Geology, Wollaston Lake, NTS Area 64L; Sask. Energy Mines, Rep. 211, 1:250 000 scale map with marginal notes.

Tran, H.T. 2001. Tectonic evolution of the Paleoproterozoic Wollaston Group in the Cree Lake Zone, Northern Saskatchewan, Canada. Ph.D. Thesis, University of Regina, Regina, Canada.

Tran, H.T., Ansdell, K.M., Bethune, K.M., Watters, B.R., and Ashton, K.E. 2003. Nd isotope and geochemical constraints on the depositional setting of Paleoproterozoic metasedimentary rocks along the margin of the Archean Hearne craton, Saskatchewan, Canada. Precambrian Research, 123: 1-28.

Tran, H.T., Ansdell, K.M., Bethune, K.M, Ashton, K.E., and Hamilton, M.A. 2008. Provenance and tectonic setting of Paleoproterozoic metasedimentary rocks along the eastern margin of Hearne craton: 
1180 Constraints from SHRIMP geochronology, Wollaston Group, Saskatchewan, Canada. Precambrian

1181 Research, 167: 171-185. Doi: 10.1016/j.precamres.2008.08.003

1182 Van Schmus, W.R., Bickford, M.E., Lewry, J.F., and Macdonald, R. 1987. U-Pb geochronology in the

1183 Trans-Hudson Orogen, northern Saskatchewan, Canada. Canadian Journal of Earth Sciences 24: 4071184424.

1185 Van Breemen, O., Harper, C.T., Berman, R.G., and Wodicka, N. 2007. Crustal evolution and

1186 Neoarchean assembly of the central-southern Hearne domains: Evidence from U-Pb geochronology

1187 and Sm-Nd isotopes of the Phelps Lake area, northeastern Saskatchewan. Precambrian Research 159:

1188 33-59. doi:10.1016/j.precamres.2007.04.014

1189 Worley, B. and Powell, R. 2000. High-precision relative thermobarometry: theory and a worked 1190 example. Journal of Metamorphic Geology 18 : 91-101. doi:10.1046/j.1525-1314.2000.00239.x

1191 Yeo, G.M., and Delaney, G. 2007. The Wollaston Supergroup, stratigraphy and metallogeny of a 1192 Paleoproterozoic Wilson cycle in the Trans-Hudson Orogen, Saskatchewan. In EXTECH IV: Geology 1193 and Uranium Exploration Technology of the Proterozoic Athabasca Basin, Saskatchewan and Alberta. 1194 Edited by C.W. Jefferson and G. Delaney. Geology Survey of Canada, Bulletin 588, (also Geological 1195 Association of Canada, Mineral Deposits Division, Special Publication 4; Saskatchewan Geological 1196 Society, Special Publication 18), pp.89 -117. 


\section{Tables}

1198 Table 1: Comparison of deformation phases defined in previous works and those in the WMTZ in this

1199 study.

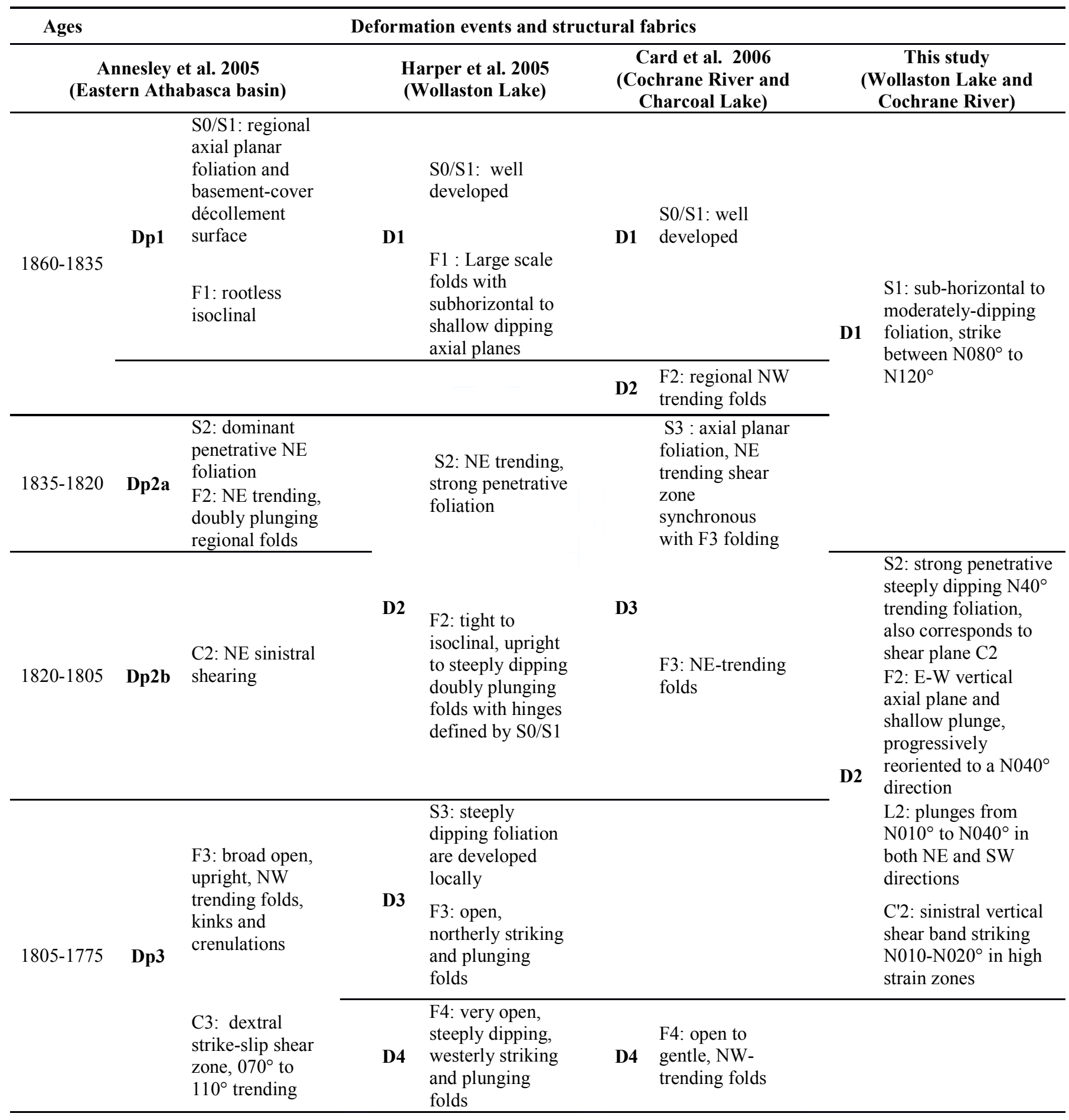


1201 Table 2: Whole-rock geochemical analyses of samples discussed in the text and used for 1202 thermodynamic calculations

\begin{tabular}{ccccccccc}
\hline Localisation: & Wolly & Wolly & Wolly & Wollaston & Wollaston & Wollaston & Cochrane & Cochrane \\
\hline Sample: & $\mathrm{TC} 33$ & LS68 & $\mathrm{TC} 34$ & $12 \mathrm{~W} 008$ & $12 \mathrm{~W} 106$ & $13 \mathrm{~W} 048$ & $13 \mathrm{~W} 023$ & $12 \mathrm{~W} 022 \mathrm{C}$ \\
\hline $\mathrm{SiO}_{2}$ & 59,79 & 41,38 & 54,30 & 47,64 & 59,55 & 58,57 & 50,46 & 60,27 \\
\hline $\mathrm{TiO}_{2}$ & 1,07 & 1,98 & 1,18 & 1,71 & 0,96 & 1,05 & 1,21 & 0,89 \\
\hline $\mathrm{Al}_{2} \mathrm{O}_{3}$ & 21,59 & 29,54 & 24,66 & 28,73 & 17,93 & 18,88 & 26,06 & 18,35 \\
\hline $\mathrm{FeO}$ & 7,31 & 13,17 & 8,26 & 13,35 & 8,67 & 8,66 & 11,28 & 8,61 \\
\hline $\mathrm{MnO}$ & 0,07 & 0,54 & 0,08 & 0,11 & 0,08 & 0,08 & 0,17 & 0,04 \\
\hline $\mathrm{MgO}$ & 2,10 & 3,66 & 2,72 & 2,38 & 3,37 & 3,19 & 3,77 & 2,87 \\
\hline $\mathrm{CaO}$ & 0,69 & 0,35 & 0,16 & 0,96 & 1,11 & 1,60 & 0,81 & 0,34 \\
\hline $\mathrm{Na}_{2} \mathrm{O}$ & 0,65 & 0,19 & 0,00 & 1,30 & 2,00 & 2,28 & 1,03 & 1,50 \\
\hline $\mathrm{K}_{2} \mathrm{O}$ & 4,40 & 2,10 & 3,31 & 1,16 & 3,37 & 3,03 & 2,41 & 4,73 \\
\hline $\mathrm{P}_{2} \mathrm{O} 5$ & 0,05 & 0,03 & 0,05 & 0,07 & 0,18 & 0,10 & 0,07 & 0,05 \\
\hline $\mathrm{LOI}$ & 0,72 & 4,61 & 3,76 & 0,40 & 0,92 & 1,05 & 0,63 & 0,51 \\
\hline Total & 99,30 & 99,10 & 99,45 & 99,34 & 99,15 & 99,48 & 99,20 & 99,14 \\
\hline
\end{tabular}

1205 Table 3: Representative chemical compositions of minerals used to constrain P-T conditions

\begin{tabular}{|c|c|c|c|c|c|c|c|c|c|}
\hline \multicolumn{2}{|l|}{ Localisation: } & $\begin{array}{l}\text { Wolly- } \\
\text { McClean }\end{array}$ & $\begin{array}{l}\text { Wolly- } \\
\text { McClean }\end{array}$ & $\begin{array}{l}\text { Wolly- } \\
\text { McClean }\end{array}$ & Wollaston & Wollaston & Wollaston & Cochrane & Cochrane \\
\hline \multicolumn{2}{|l|}{ Sample: } & TC33 & TC34 & LS68 & $12 \mathrm{~W} 008$ & 12W106 & 13W048 & 13W023 & $13 \mathrm{~W} 022 \mathrm{C}$ \\
\hline \multirow{3}{*}{ Garnet } & Xalm & $0,78-0.81$ & $0.80-0.85$ & $0.80-0.82$ & $0.84-0.86$ & $0.80-0.83$ & $0.79-0.83$ & $0.75-0.79$ & $0.71-0.77$ \\
\hline & Xpy & $0.13-0.17$ & $0.11-0.16$ & $0.11-0.14$ & $0.10-0.12$ & $0.11-0.16$ & $0.11-0.16$ & $0.16-0.20$ & $0.20-0.25$ \\
\hline & Xgrs & $\begin{array}{c}0.030- \\
0.034\end{array}$ & $\begin{array}{l}0.021- \\
0.026\end{array}$ & $\begin{array}{c}0.020- \\
0.024\end{array}$ & $0.024-0.026$ & $0.022-0.023$ & $0.026-0.029$ & $0.023-0.028$ & $0.015-0.030$ \\
\hline Biotite & $\mathbf{X}_{\mathrm{Mg}}$ & $0.41-0.54$ & $0.36-0.54$ & $0.33-0.40$ & $0.30-0.36$ & $0.38-0.53$ & $0.39-0.45$ & $0.42-0.54$ & $0.40-0.60$ \\
\hline Cordierite & $\mathrm{X}_{\mathrm{Mg}}$ & $0.56-0.58$ & - & - & $0.46-0.49$ & $0.57-0.63$ & $0.57-0.59$ & $0.58-0.65$ & $0.62-0.67$ \\
\hline Plagioclase & Xan & $0.38-0.42$ & - & - & 0.29 & $0.20-0.24$ & $0.26-0.30$ & $0.29-0.33$ & 0.20 \\
\hline \multicolumn{10}{|c|}{ Note: The compositions were acquired with an electron microprobe. -: not analyzed; Xalm (Almandine) $=\mathrm{Fe} /$} \\
\hline
\end{tabular}




\section{Captions}

1211 Figure 1: (a) Map of North America showing the location of the Archean Churchill and Superior 1212 cratons, which were welded by the Paleoproterozoic Trans-Hudson Orogen (THO) (modified after 1213 Jefferson et al. 2007). (b) Simplified geological map of the western Canadian Shield (modified after 1214 Berman et al. 2005). Paleo- to Mesoproterozoic basins within the Canadian Shield that contain 1215 unconformity-associated uranium deposits (e.g. Athabasca (A)) or are considered to have potential for 1216 them (e.g. Thelon (T)) are plotted, as well as the major tectonic elements of the northwestern Canadian 1217 Shield. Abbreviations: WMTZ - Wollaston-Mudjatik Transition Zone; TTZ - Taltson magmatic zone; 1218 TMZ - Thelon magmatic zone; STZ - Snowbird tectonic zone; VRSZ - Virgin River shear zone. (c)

1219 Lithotectonic domains of the exposed portion of the Hearne Province in northern Saskatchewan, 1220 encompassing parts of the Mudjatik and Wollaston Domains. The location of McClean Lake is plotted, 1221 as well as several unconformity-type uranium deposits within the Athabasca Basin. The study area is 1222 outlined by the black rectangle and shown in more detail in Fig 2.

Figure 2: Regional geological map of the Wollaston Lake area based on both the bedrock mapping and airborne geophysical maps (compiled and modified after Harper et al. 2007, Card et al. 2006, and Thomas et al. 1983). The shaded region corresponds to the location of the WMTZ. The three main studied domains, Wolly-McClean exploration Project, Wollaston Lake, and Cochrane River are highlighted.

Figure 3: Simplified geological and structural map, with a NW-SE cross-section of the northern shore of the Wollaston Lake (geological map modified after Harper et al. 2007b). Map shows simplified foliation trajectories and sampling locations of Paleoproterozoic supracrustal Wollaston Group and Archean basement. 
1235

1236

1237

1238

1239

1240

1241

1242

1243

1244

1245

1246

1247

1248

1249

1250

1251

1252

1253

1254

1255

1256

1257

1258

1259

1260

1261

1262

Figure 4: Simplified geological and structural map, with a NW-SE cross-section of Cochrane River (geological map modified after Card et al. 2006b). Map shows simplified foliation trajectories and sampling locations of Paleoproterozoic supracrustal Wollaston Group and Archean basement.

Figure 5: Outcrop photos showing examples of subhorizontal S1 gneissic foliation (in dotted red line). ( $a$ and $b$ ) S1 foliation in the Archean basement exposed to north of Crozier Island. 3 generations of pegmatite have been distinguished. (A) Leucocratic pegmatite syn-S1 foliation. (B) Pink pegmatite that cross-cut slightly the first generation. This suggests that this pegmatite is post-S1 and pre-F2 folding (C) Pink pegmatite parallel to the axial plane of F2 folds that affect the two previous generations. (c) S1 foliation in Archean amphibolite observed in the north of Shaganappie Island, locally affected by sinistral vertical S2/C2 shear bands. ( $d$ and e) Microlithons of S1 foliation in paleoproterozoic grt-crd-bearing pelitic gneiss respectively to the north-east of Kendel Island and to the north-east of Lejour Island. (f) S1 foliation in paleoproterozoic grt-crd-bearing pelitic gneiss, on small island South of Shaganappie Island, folded by decimeter scale open F2 folds with steeplydipping axial planes related to the development of cordierite.

Figure 6: Outcrop photos of D2 structures. (a) Penetrative steeply dipping S2 foliation striking $\sim$ NE, in the Archean basement east of the elbow on the Cochrane River. (b) S2 foliation axial plane of F2 folds affecting pink pegmatite intrusion, observed in Archean basement on the south shore, east of the elbow on the Cochrane River. ( $c$ and $d$ ) Vertical pink pegmatites emplaced along F2 axial plane, on the north shore, east of the elbow on the Cochrane River. (e) Penetrative steeply dipping S2 foliation striking $\sim \mathrm{NE}$, in paleoproterozoic Calc-silicate rocks on a small island, south of Shaganappie Island. (f) S2 foliation defined by millimeter-to centimeter-wide leucosomes, in paleoproterozoic grt-crdbearing pelitic gneiss, north-east of Kendel Island in the Wollaston Lake.

Figure 7: Outcrop photos showing sinistral C2' shear bands (a) S2/C2 foliation locally affected by sinistral vertical C2' shear bands intruded by pegmatites, in the Archean basement, on crozier Island in the Wollaston Lake. (b and c) S2/C2 foliation locally affected by sinistral vertical C2' shear bands 
1263

1264

1265

1266

1267

1268

1269

1270

1271

1272

1273

1274

1275

1276

1277

1278

1279

1280

1281

1282

1283

1284

1285

1286

1287

1288

1289

1290

intruded by leucosomes in Paleoproterozoic grt-crd-bearing pelitic gneiss (b) on the North-east shore of Fife Island in the Wollaston Lake, (c) to the north-east of Lejour Island, in the Wollaston Lake. (d) Ductile sinistral vertical C2' shear bands reactivated under brittle conditions, in Paleoproterozoic psammitic gneiss, on small island to the south-east of Shaganappie Island.

Figure 8: Structural data of northern part of Wollaston Lake study area. (a) S1 and S2 foliation map. (b) Stereonets summarizing data of D1 and D2 deformation phases. (c) Lineation and fold axis map. (d) Stereonet summarizing data of lineation and fold axis data. (stereograms built using the program open stereo; Wulff stereograms, lower hemisphere).

Figure 9: Structural data of Cochrane River study area. Same caption information as Figure 8.

Figure 10: Schematic diagram showing the progressive ductile strain evolution. The location of Wolly-McClean exploration drilling project (D), Wollaston Lake (W) and Cochrane River (C) are plotted for each stage. (1) Formation of a shallow dipping S1 foliation and folding of this foliation by F2 folds with east-west vertical axial plane and shallow plunge. (2) Anti-clockwise rotation of preexisting S1 foliation, lineation and early East-West oriented F2 folds towards a N040 ${ }^{\circ}$-direction. The progressive verticalization of the pre-existing F2 hinges is directly related to the sinistral shearing that tends to produce curviplanar drag folds (Choukroune 1995). This evolution of F2 fold direction is interpreted to be the effect of the D2 sinistral shearing. D2 deformation is partitioned between high strain zones and low strain zones where early F2 folds and S1 foliation are preserved. In D2 high strain zones, S2 foliation corresponds to shear plane $\mathrm{C} 2$, and is referred to as $\mathrm{S} 2 / \mathrm{C} 2$ foliation. (3) Development of discrete and localized sinistral vertical C2' shear band, striking N10 in high strain zones.

Figure 11: Outcrop photos and photomicrographs. (a) A partially melted grt-crd bearing pelitic gneiss consisting of porphyroblasts of garnet (Grt), biotite (Bt), sillimanite (Sil), and quartzofeldspathic leucosome (melt), north-east of Kendel Island in the Wollaston Lake. (b) Partially melted 
1291 grt-crd-bearing pelitic gneiss with abundant leucosomes that contain millimeter wide peritectic

1292 cordierite, north-east of Lejour Island, in the Wollaston Lake. (c) Grt-crd bearing pelitic gneiss, North-

1293 West of Crozier Island in the Wollaston Lake). Garnet occurs as pluri-millimeter-size porphyroclats in

1294 a quartzo-feldspathic leucosome. (d) Thin section scan of the garnet-cordierite-bearing pelitic gneiss

1295 shown in (c). Garnet contains inclusions of biotite, feldspar, and ilmenite. The S2 foliation consists of

1296 biotite and sillimanite wrapping around garnet. Cordierite is mostly present within the pressure

1297 shadows of peritectic garnet.

1298

1299

Figure 12: Photomicrograph of garnet-cordierite-bearing pelitic gneiss with the localization of the

garnet profiles shown in figure 13. (a) Pelitic gneiss (drill-core LS68) containing feldspar (Kfs),

porphyroblasts of garnet (Grt) wrapped by the $\mathrm{S} 2$ foliation consisting of biotite (Bt), sillimanite (Sil),

Rutile (Rt) from the northern part of the Wolly-McClean exploration drilling project (WMEDP). (b)

Pelitic gneiss (sample 12w008 - North-West of Crozier Island in Wollaston Lake) containing

1304

porphyroblasts of garnet wrapped by the $\mathrm{S} 2$ foliation consisting of biotite, sillimanite, ilmenite (Ilm)

and cordierite (Crd) developed at the expense of garnet. (c) Pelitic gneiss (sample 13w048- on small

island to the South-east of Shaganappie Island) consisting of quartz (qtz), porphyroblasts of garnet wrapped by the S2 foliation consisting of biotite, sillimanite, and cordierite developed at the expense of garnet. (d) Quartz-undersaturated pelitic gneiss (sample 13w023A - on the south shore, east of the elbow on the Cochrane River) consisting of porphyroblasts of garnet, cordierite developed at the expense of garnet, sillimanite, ilmenite, and spinel (Hercynite $=\mathrm{Hc})$ observed in equilibrium with the retrograde cordierite. Cordierite also occurs as porphyroblasts elongated parallel to the S2 foliations and containing sillimanite needles. (e) Psammopelitic gneiss (drill-core SL54) from the southern part of the WMEDP, consisting of graphite (Gr), biotite, that defines the S2 foliation, and a strong retrogression of porphyroblasts of cordierite into chlorite. (f) Psammopelitic gneiss (drill-core MC15A) from the southern part of the WMEDP, consisting of quartz, large flakes of graphite that define, with the biotite, the $\mathrm{S} 2$ foliation, and a strong retrogression of porphyroblasts of garnet into cordierite which is itself almost entirely retrogressed into chlorite. 
1319

1320

1321

1322

1323

1324

1325

1326

1327

1328

1329

1330

1331

1332

1333

1334

1335

1336

1337

1338

1339

1340

1341

1342

1343

1344

1345

1346

Figure 13: Chemical profiles of garnet from the grt-crd-bearing pelitic gneiss. See Figure 12 for location.

Figure 14: Left: Calculated P-T pseudosections for three representative grt-crd bearing pelitic gneiss compositions from (a) Wolly-McClean exploration Project, (c) Wollaston Lake and (e) Cochrane River. Diagrams are contoured for grossular content in garnet (dashed black lines) and $\mathrm{X}_{\mathrm{Mg}}(\mathrm{Mg} /$ $(\mathrm{Mg}+\mathrm{Fe}))$ in cordierite (dashed grey lines). Right: Summary diagram of $\mathrm{P}-\mathrm{T}$ estimates for all samples in each studied area. (b) Drill core: TC33-LS68-TC34 and LS70. (d) Samples 12W008, 12W106, 12W075a, 12W075b, 12W096 and 13W048. (f) Samples 13W023A and 13W022C. For each sample, garnet-in, cordierite-in, kyanite-in, and mica-in reactions are reported as solid green, blue, grey, and yellow lines, respectively. The thick solid black line represents the solidus. Red field represent the peak assemblage recorded by the maximum grossular content in garnet and interpreted as the M1-D1 event assemblage. The black fields represent the P-T conditions of the M2-D2 event based on the $\mathrm{X}_{\mathrm{Mg}}$ contents of cordierite. $1 \mathrm{kbar}=100 \mathrm{MPa}$

Figure 15: Summary diagram of the finite strain pattern and the thermobarometric estimates of the Wollaston Lake study area. $1 \mathrm{kbar}=100 \mathrm{MPa}$

Figure 16: Simplified crustal-scale cross-sections showing the evolution of the MWTZ. (a) Initial stage: thinned Archean Hearne passive margin with Paleoproterozoic basins (Wollaston supracrustal sequence deposition).(b) M1-D1 event: thickening of the Hearne margin by burial and underthrusting of the thinned margin after the docking of the Reindeer Zone with the Hearne Craton. This event is characterized by the development of a gently-dipping S1 foliation in the future WMTZ and Wollaston Domain as well as in the Rottenstone Domain (noted as S1 C\&C, 2009) (Culshaw and Clarke, 2009)

(c) M2-D2 event: exhumation between D1 and D2 in response to isostatic re-equilibration and development of D2 vertical shear zone during a sinistral transpression. D2 deformation is mostly localized in the WMTZ where partial melting of the Wollaston metasediments is widespread. Note that the D2 sinistral transpression is oriented NE-SW, so in addition to the vertical motion there is also 
1347 a significant horizontal displacement that brings the Wolly-McClean area more to the SW. The pink, 1348 orange, and green round symbols show the inferred locations of the studied areas during the initial 1349 stage, M1-D1 event and M2-D2 event. At M2-D2, the symbols with transparent background represent 1350 the location of the studied areas during D1. The D2 geometry is based on the seismic line S2b and

1351

1352

1353

1354

1355

1356

1357

1358

1359

1360

1361

1362

1363

1364

1365

1366

1367

1368

1369

1370

1371

1372

1373

1374 associated interpreted cross-section of Corrigan et al. (2005) and Culshaw and Clarke (2009). The thick black line in figure (b) and (c) marks the suture between the Reindeer Zone and the Hearne Craton. In all figures, the present erosion level is shown. 


\section{Supplementary material}

1376

1377 Figure S1: Calculated P-T pseudosections for three representative grt-crd bearing pelitic gneiss compositions one from each of Wolly-McClean exploration Project (a), Wollaston Lake (b) and Cochrane River (e). The red field represents the peak phase assemblage recorded by the maximum grossular content in garnet and interpreted as the M1-D1 event assemblage. The black field represents the phase assemblage field after decompression based on the $\mathrm{X}_{\mathrm{Mg}}$ contents of cordierite and interpreted as the M2-D2 event assemblage. Phase diagrams are contoured for modes garnet in volume \% (dashed 1383 colored lines).

1384 


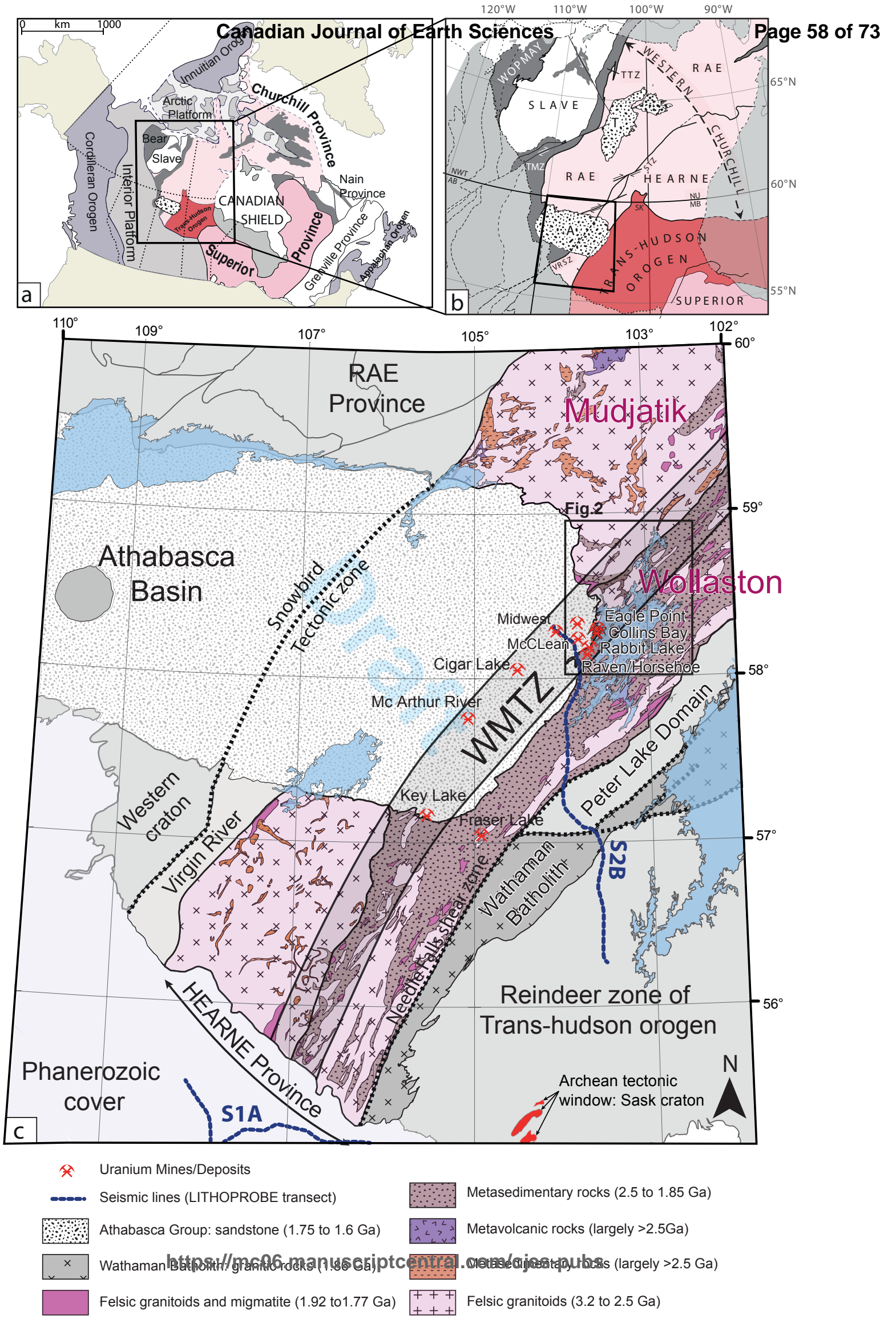




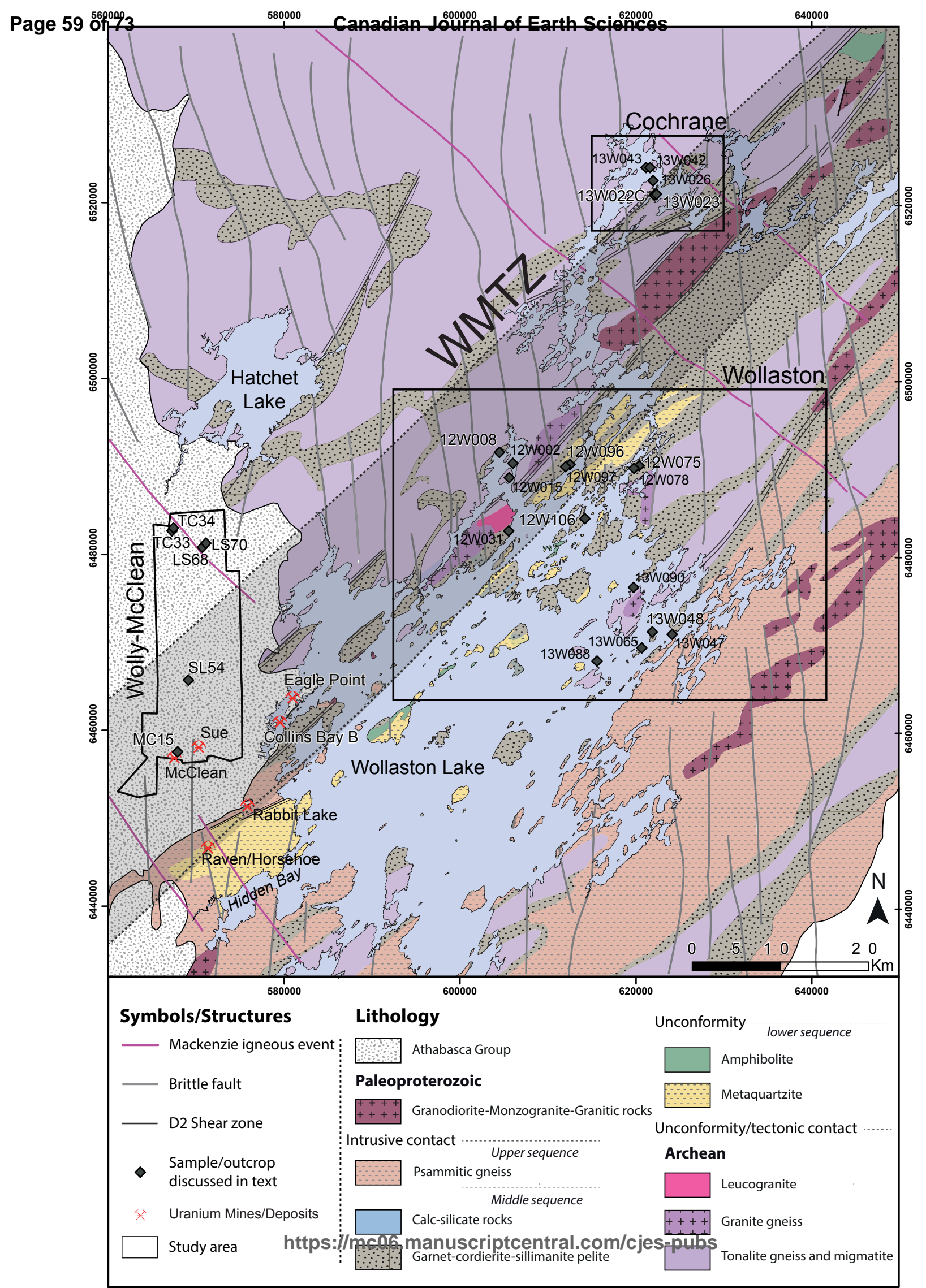



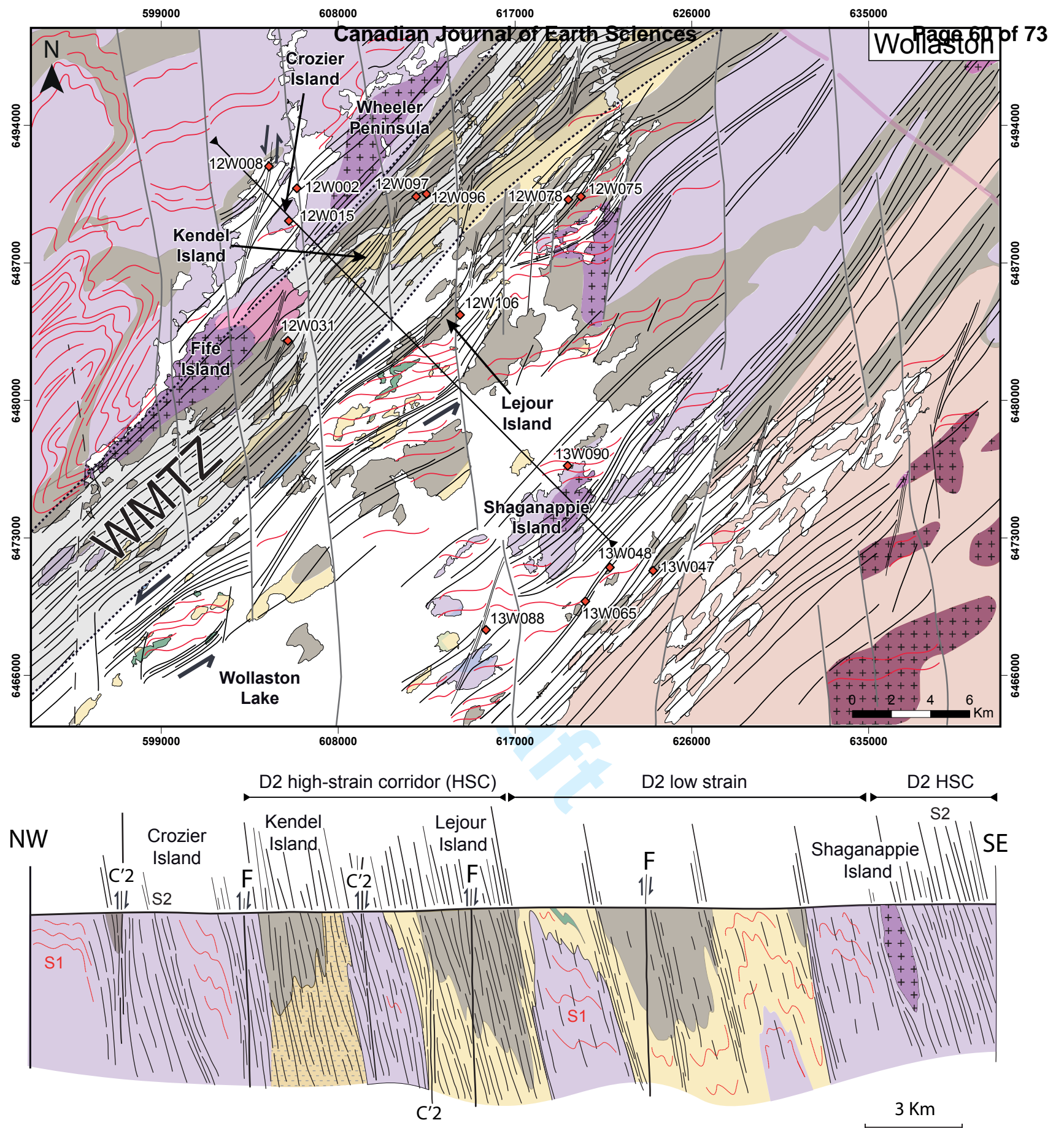

Symbols/Structures

_ Mackenzie igneous event

— Brittle fault

- D2 deformation

D1 deformation

Sample/outcrop discussed in text

\section{Lithology}

\section{Paleoproterozoic}

\begin{tabular}{|l|l}
++++ \\
$+++t$
\end{tabular} Granodiorite-Monzogranite-Granitic rocks

Intrusive contact

Upper sequence

Psammitic gneiss
Unconformity

lower sequence

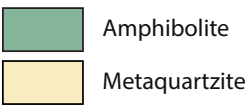

Unconformity/tectonic contact

Archean

Leucogranite

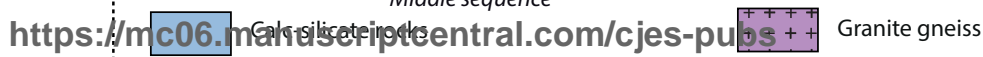




\section{Page 61 of $73 \quad 617000$}

Canadian Journal of Earth Sciences ${ }^{626000}$
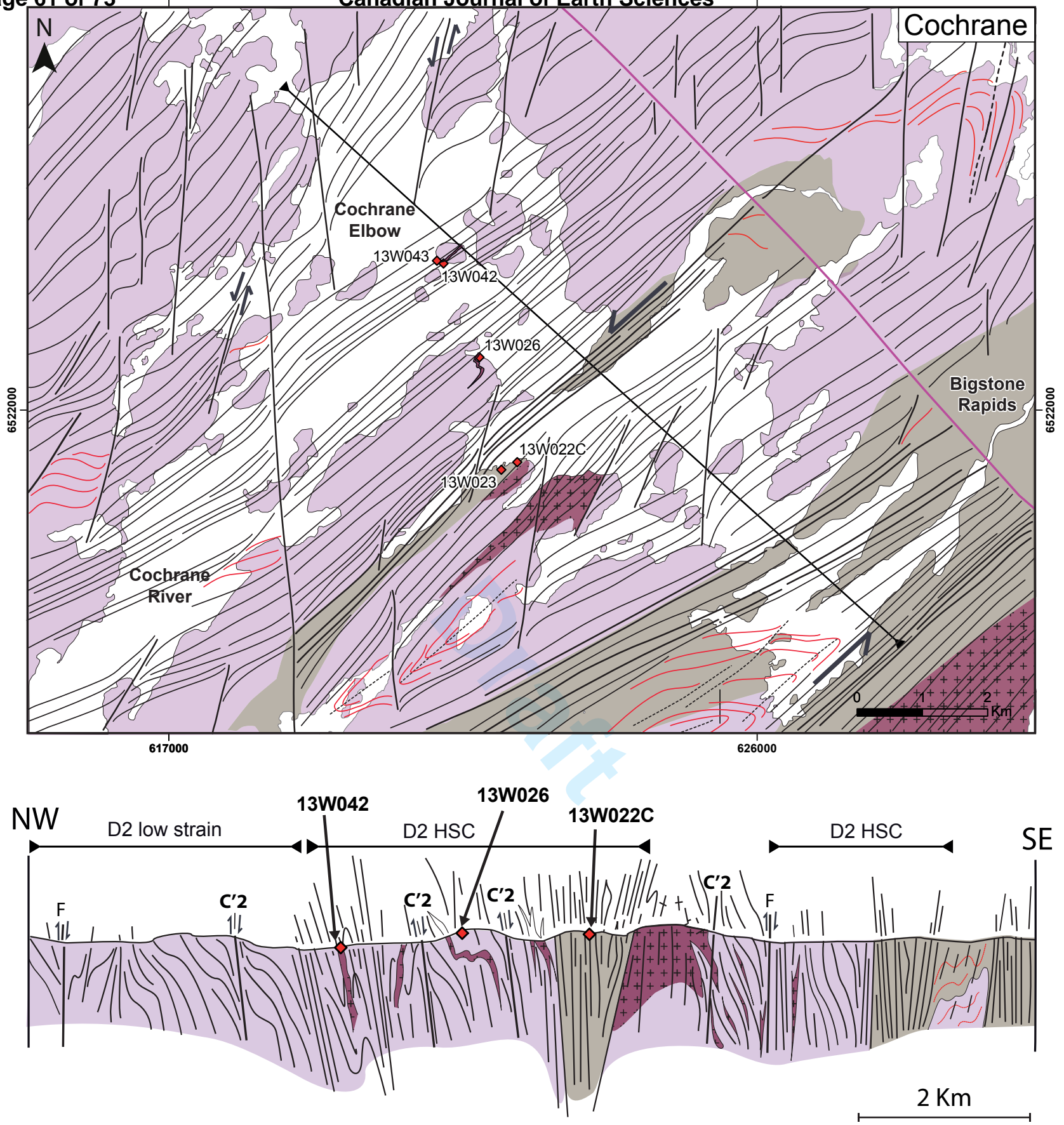

Symbols/Structures

- Mackenzie igneous event

- Brittle fault

- D2 deformation

D1 deformation

$\checkmark \quad$ Sample/outcrop discussed in text https://mc06.manuscriptcentral.com/cjes-pubs

\section{Lithology}

\section{Paleoproterozoic}

Granodiorite-Monzogranite-Granitic rocks Unconformity/tectonic contact

Archean

Intrusive contact

Middle sequence

Tonalite gneiss and migmatite 

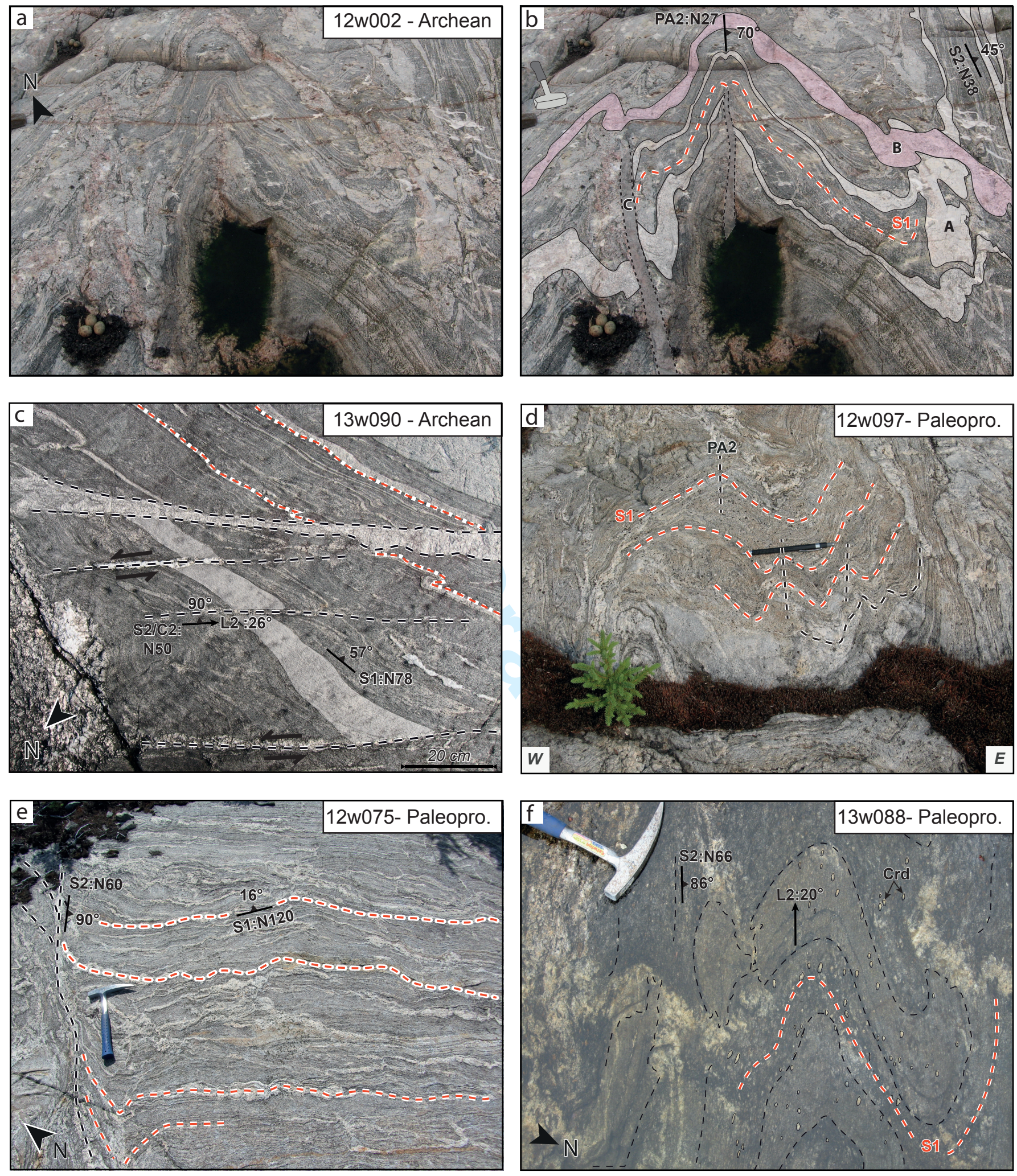

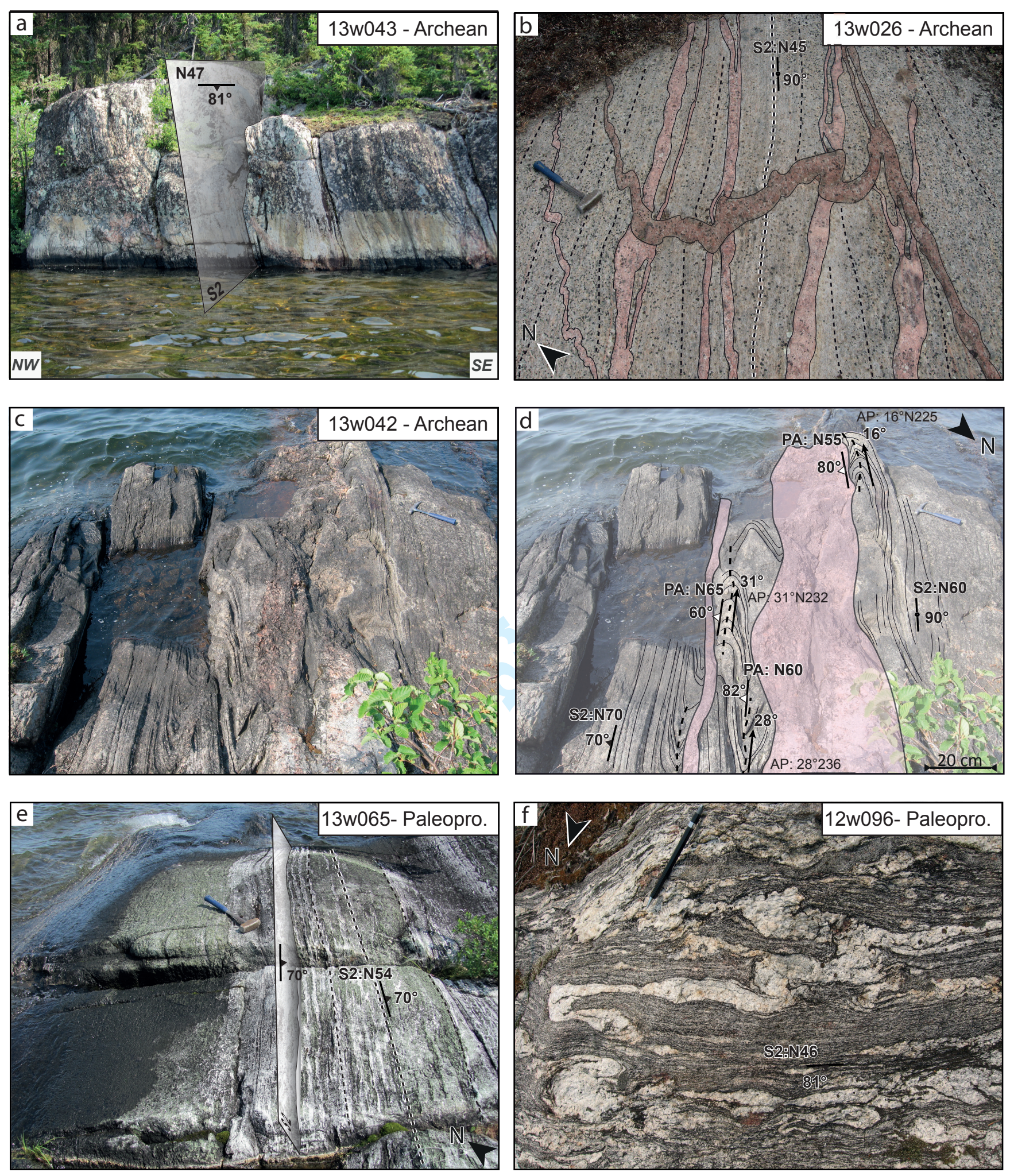

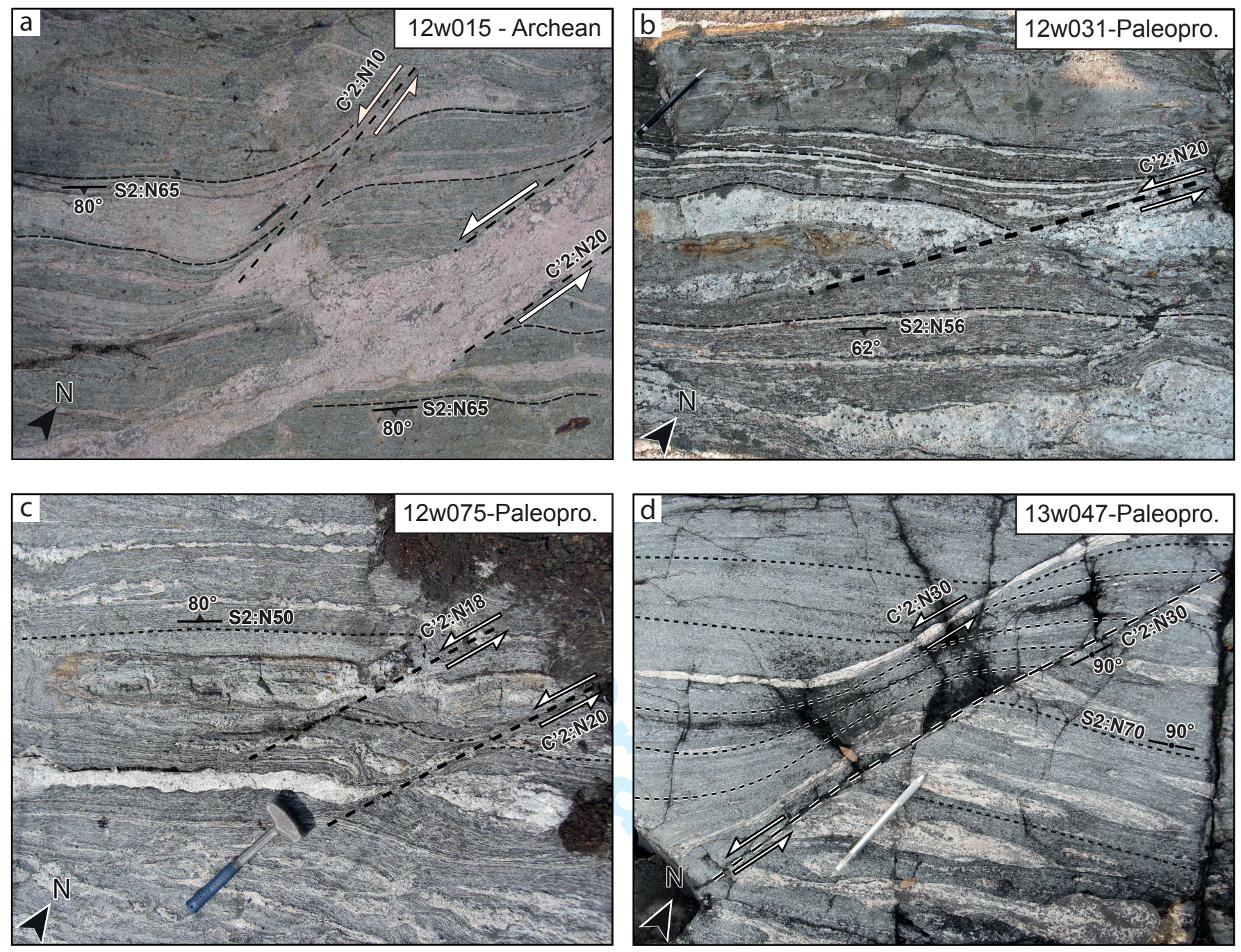


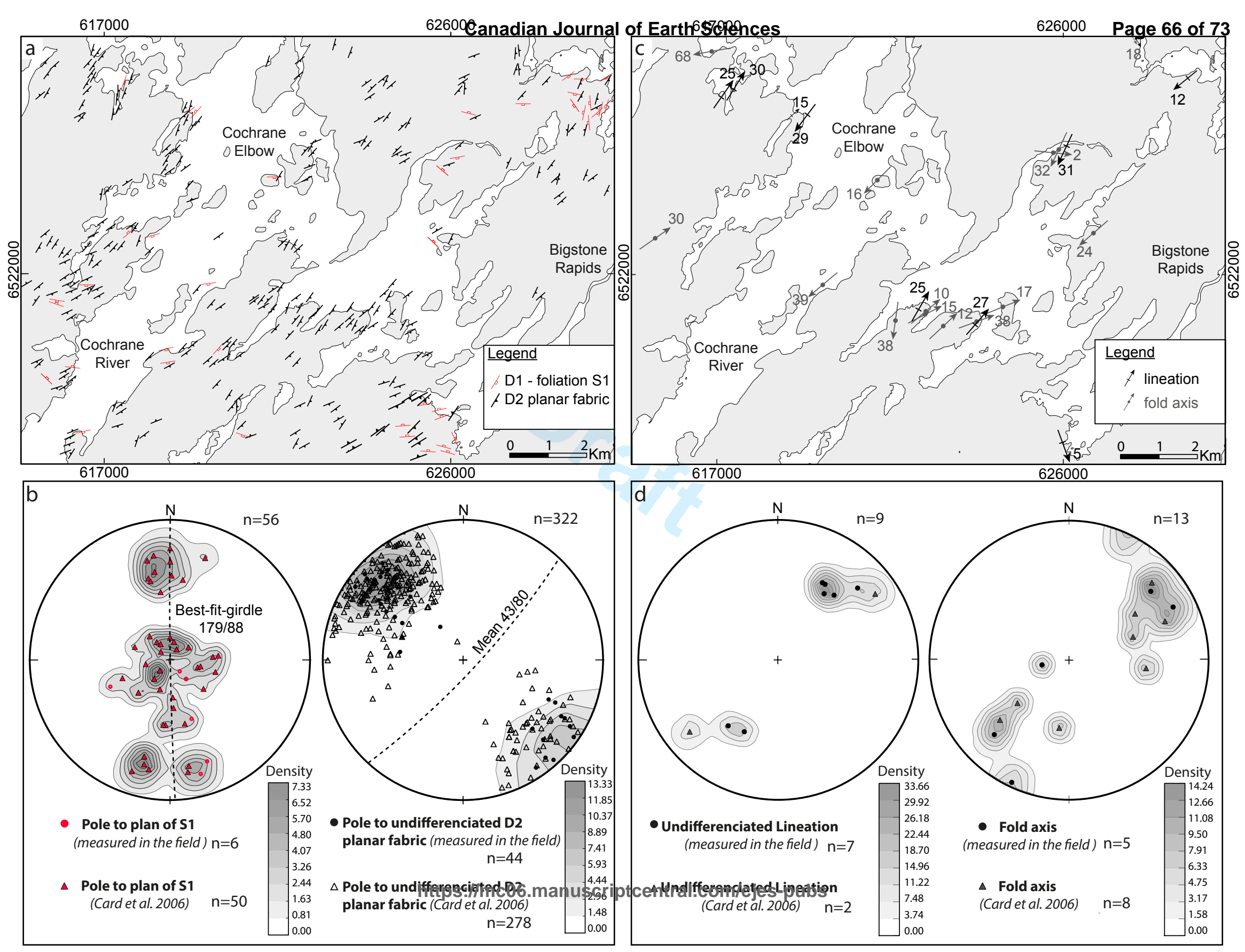



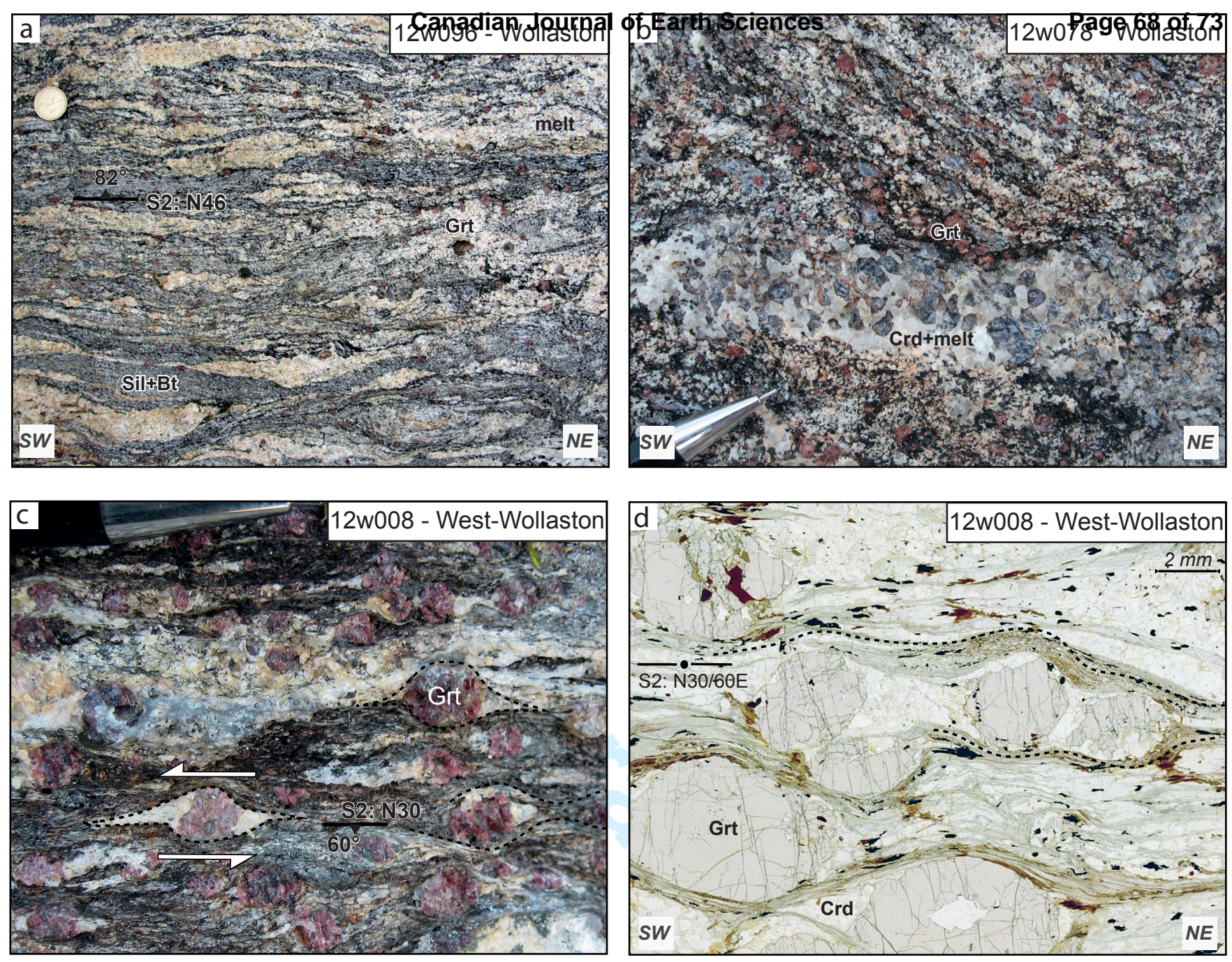


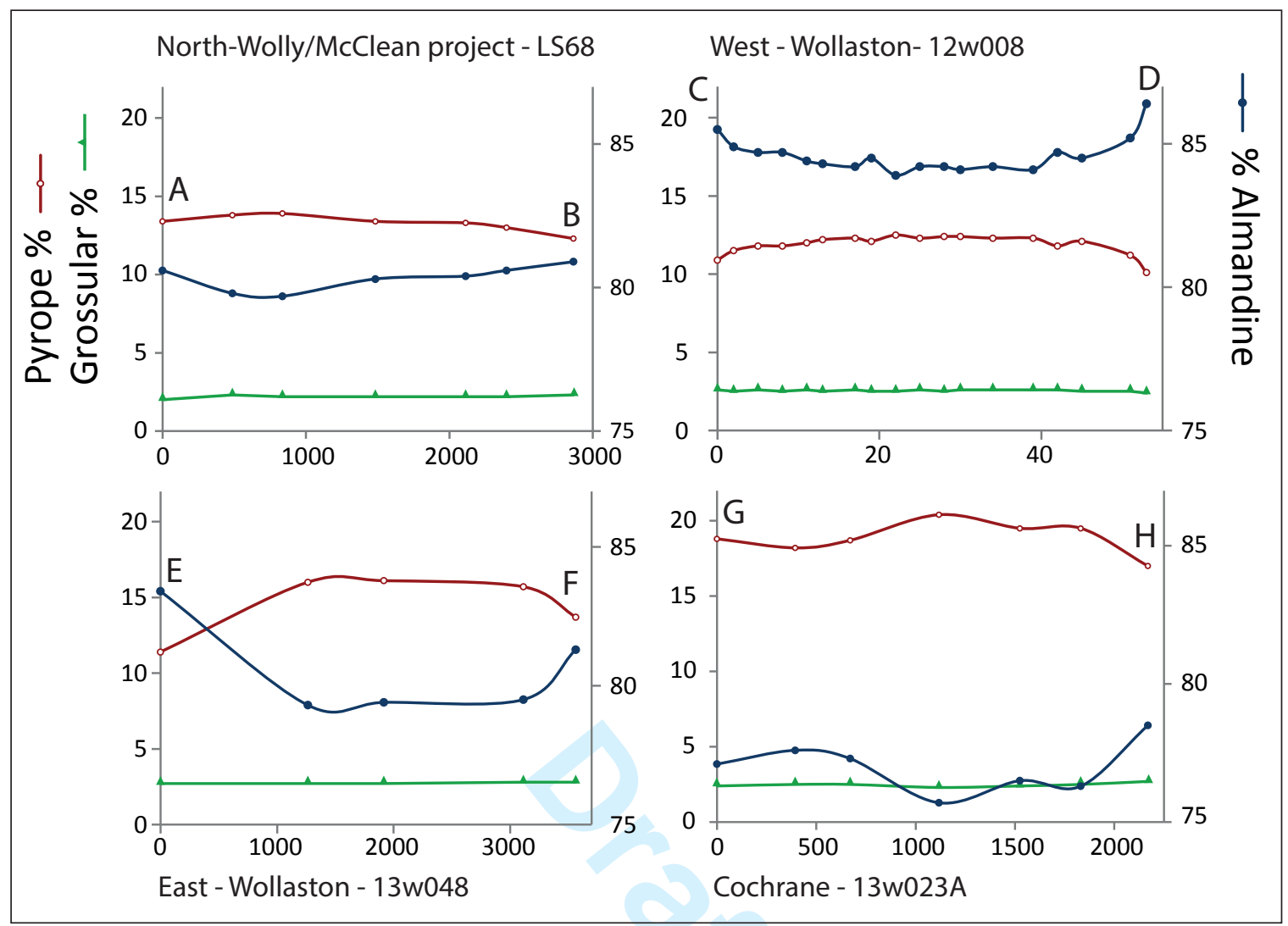




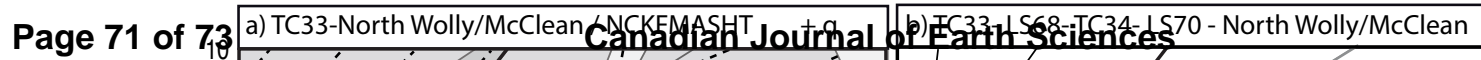
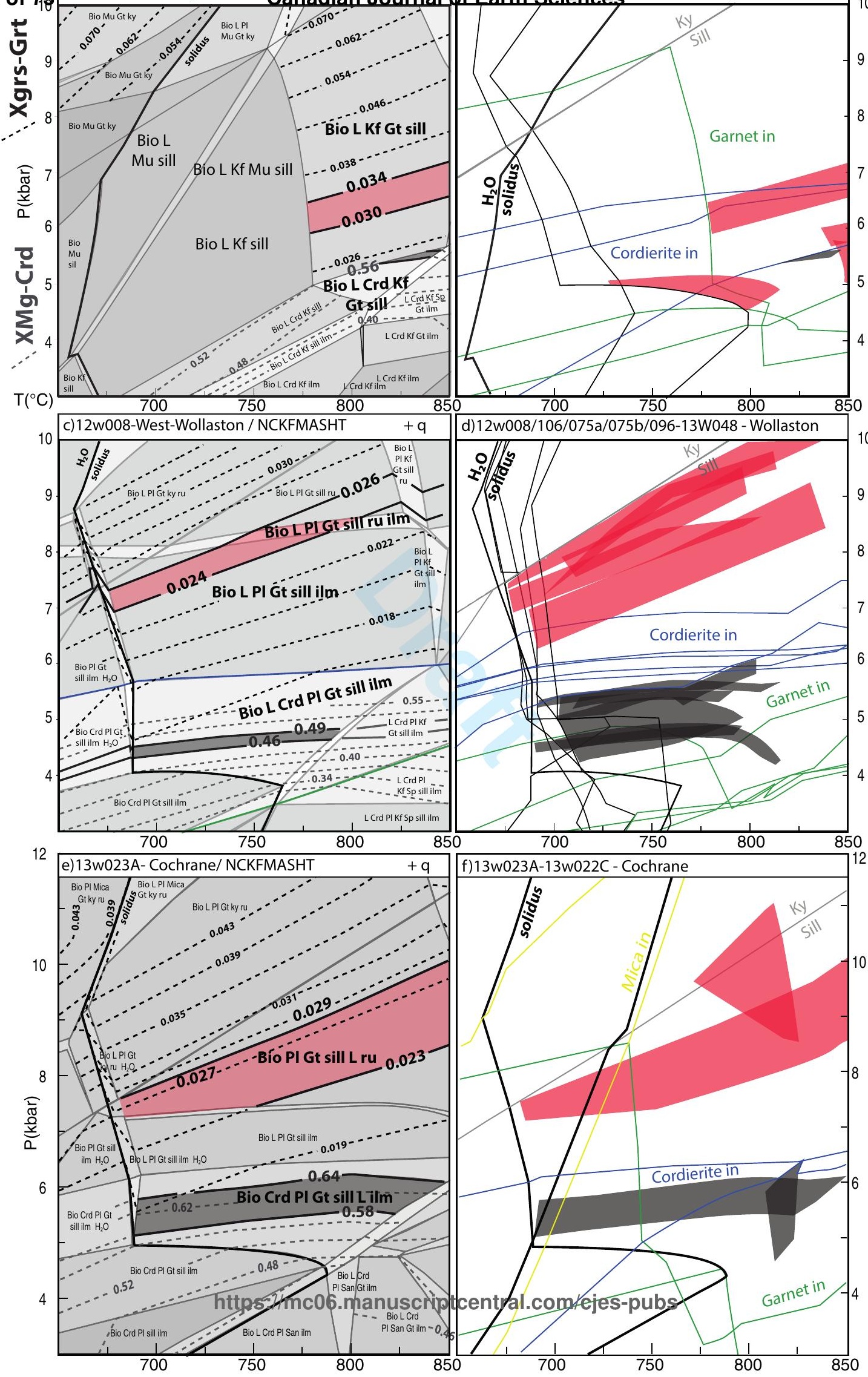


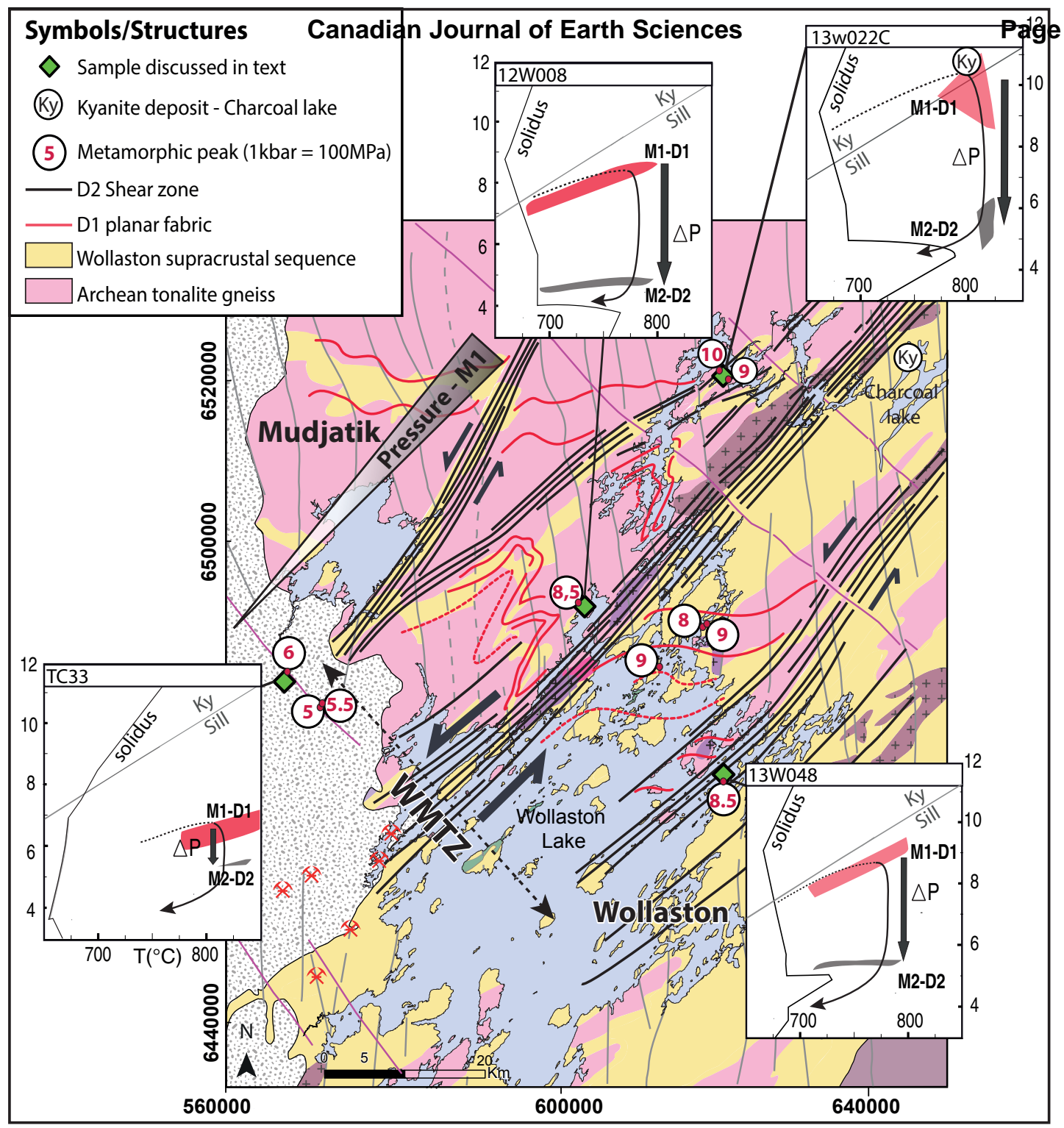


a Initial stage prior to the amalgamation of the Hearne margin with the Rottenstone arc (Reindeer zone) and the emplacement of the Wathaman batholith @ 1.86 Ga

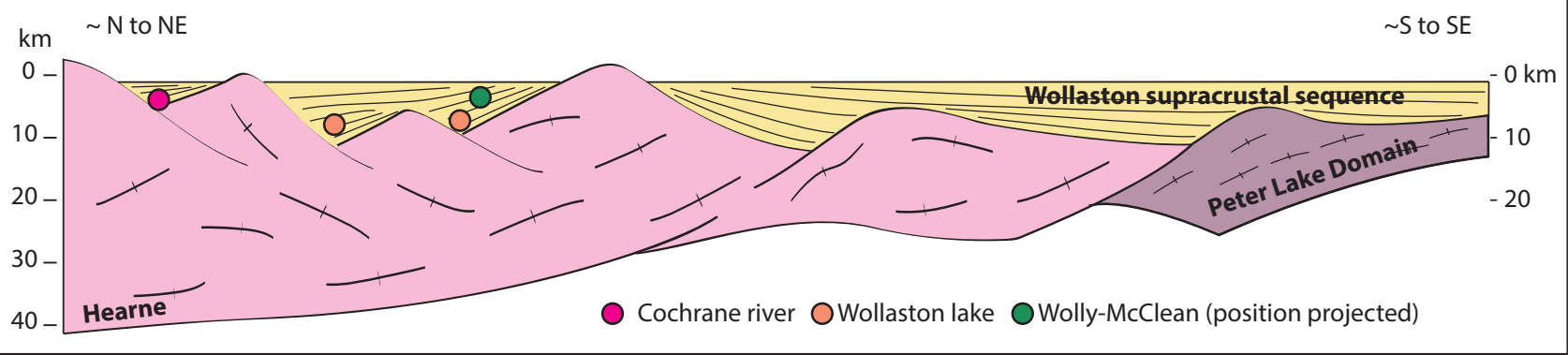

b M1-D1 event : early collision and thichening @ 1.82 Ga after the docking of the Rottenstone domain and emplacement of the Wathaman batholith (@ 1.82 Ga)

$\sim \mathrm{N}$ to $\mathrm{NE}$

$\sim S$ to $S E$

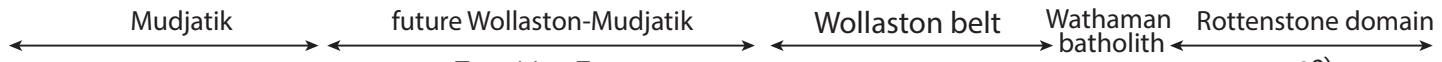
Transition Zone

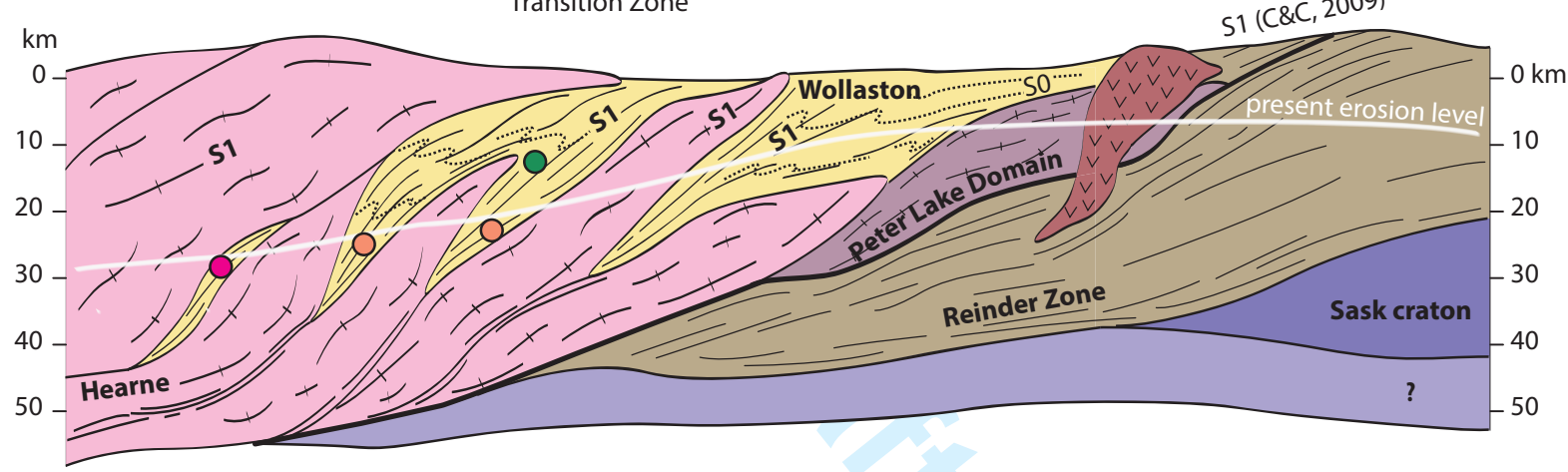

50 km

NW
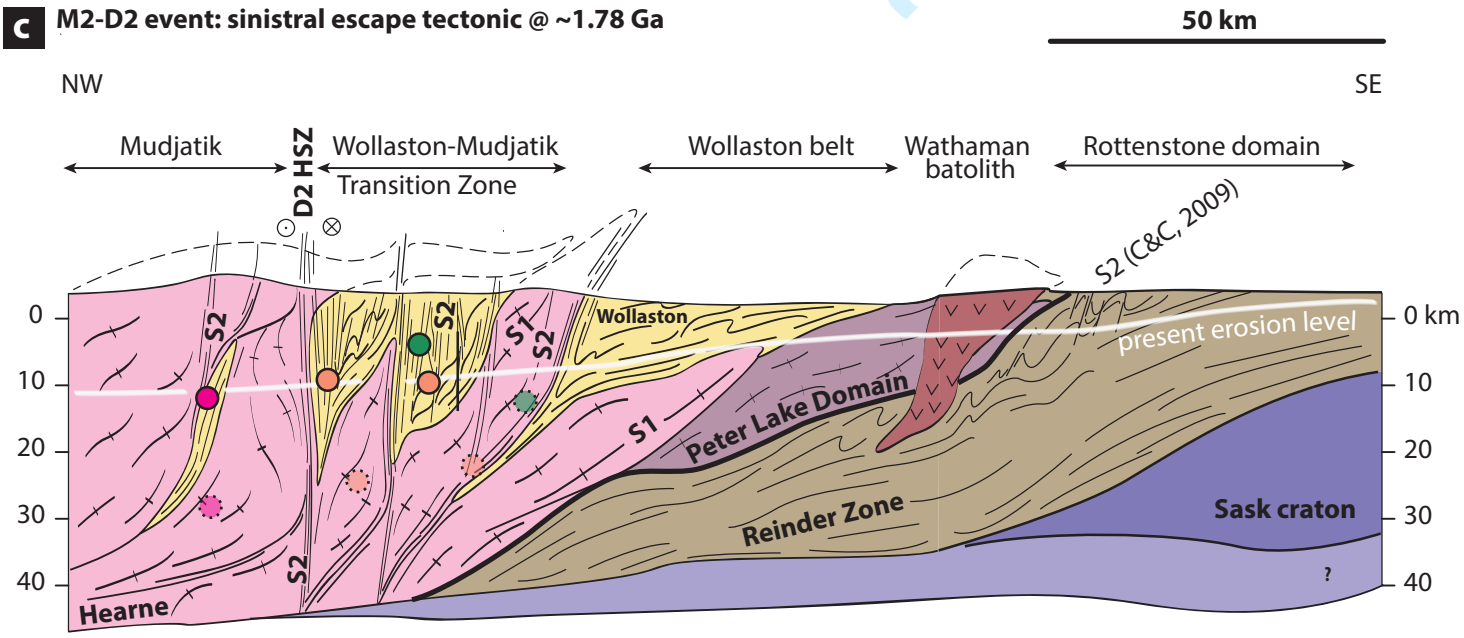